\title{
Unravelling the glass trade bead sequence from Magoro Hill, South Africa: separating pre-seventeenth-century Asian imports from later European counterparts
}

\author{
Farahnaz Koleini ${ }^{1}$, Linda C. Prinsloo ${ }^{1,2^{*}}$, Wim Biemond ${ }^{5}$, Philippe Colomban ${ }^{3,4}$, Anh-Tu Ngo 3,4, \\ Jan C. A. Boeyens ${ }^{5}$, Maria M. van der Ryst ${ }^{5}$ and Koos van Brakel ${ }^{6}$
}

\begin{abstract}
Excavations conducted between 2010 and 2012 at Magoro Hill, a site in South Africa's Limpopo Province frequented or intermittently occupied by African farming communities since the first millennium $A D$, yielded a substantial glass bead assemblage. A selection of the beads was studied non-destructively by classifying them according to morphological attributes, supplemented by Raman analyses and XRF measurements. It became evident that a morphological classification of beads recovered from sites that include imports into Africa after the seventeenth century AD could be problematic due to apparent morphological similarities between earlier and later beads. This paper demonstrates the use and archaeological application of Raman and XRF measurements to separate earlier imported beads from later counterparts by identifying glass nanostructure, as well as pigments and opacifiers, which were not used in bead series pre-dating the seventeenth century AD. Results obtained from Raman and XRF measurements indicate that although some beads retrieved from Magoro Hill pre-date the seventeenth century and belong to the Indo-Pacific (K2, East Coast, Khami) and Zimbabwe series, the largest number of beads is from a later European origin. This ties in with the settlement history of the site, which suggests that it primarily served as a rendezvous for episodic rainmaking rituals before it became the stronghold and capital of a Venda chiefdom, headed by the Magoro dynasty, in the second half of the eighteenth century AD. The comparative analysis of the long bead sequence sheds new light on changing patterns in the availability, range, consumption and origin of glass trade beads imported into the northern interior of South Africa over a period of about 1000 years.
\end{abstract}

\section{Background}

A considerable demand for ivory, rhinoceros horn and gold drew foreign traders towards trading centres along the eastern and southern coasts of Africa since earliest times. Glass beads, which were highly prized by African communities for use as everyday adornment, ceremonial costumes or objects of barter, featured high on the list of imported items that were exchanged for these commodities. From the eighth to the sixteenth century AD

\footnotetext{
*Correspondence: Iprinslo@uow.edu.au

${ }^{2}$ Centre for Archaeological Science, School of Earth and Environmental Sciences, University of Wollongong, Wollongong, NSW 2522, Australia Full list of author information is available at the end of the article
}

the market was dominated by supplies from South Asia (India) and Southeast Asia. With the arrival of European traders in southern Africa the trade routes slowly shifted from India towards Europe and, from the mid-seventeenth century onwards, European beads conquered the market [1]. Noticeable modifications in the morphology and chemistry have been observed in some of the beads traded from the eighth to the sixteenth century. These variations can be linked to different and/or shifting production centres, thus turning beads into useful chronological markers of archaeological sites [2-6]. Some of the beads originating from Europe have specific morphological features that easily distinguish them from the earlier beads $[4,7-9]$ but some are imitations of earlier beads, 
or visually resemble them, making classification on morphological parameters alone difficult. In such cases it is imperative to study differences in glass structure and chemistry, as well as pigments and opacifiers, which can be useful factors to accurately date a bead and trace its origin. The colouring of glass is an advanced technology, and innovation in the preparation of new pigments that can be attributed to specific time periods offers unique techno-chronologic markers. Such an example is the identification of a selenium-based pigment colouring moulded red glass beads (Fig. 1), retrieved from a secure archaeological context on Magoro Hill, as nano- ( $\mathrm{Zn}, \mathrm{Cd})$ $\mathrm{S}_{\mathrm{x}} \mathrm{Se}_{\mathrm{x}-1}$ mixed crystals [10]. This pigment was only produced on a large scale in the late 1920s and phased out in the 1990s in response to public concern about toxic cadmium in the environment. This implies that the economic use of cadmium pigments was limited to a small window of time, which facilitated the accurate dating of the beads and eliminated a pre-1920 date for the associated archaeological deposit and structure on Magoro Hill.

\section{Site history and archaeological context}

Between 2010 and 2012, a series of archaeological excavations were conducted at Magoro Hill, a prominent landmark in South Africa's Limpopo Province (Fig. 2). Research at Magoro Hill forms part of the Five Hundred Year Initiative, a multi-institutional and interdisciplinary project aimed at exploring the material imprint of Europe's interaction with African societies during the colonial era [11]. Oral historical accounts and cartographic records indicate that a pedestrian trade route, stretching from Delagoa Bay (Maputo) on the African east coast to present-day Zimbabwe, skirted Magoro Hill during early colonial times [12]. Magoro Hill's occupation by Venda speakers also overlapped with that of the northernmost colony established by Dutch-Afrikaans emigrants from the Cape at the foot of the Soutpansberg mountain range in 1848 [13]. It was therefore anticipated that the Magoro Hill investigation would uncover material cultural remains, such as glass beads, that could shed light on the ever-expanding impact of European trade and colonisation in northernmost South Africa.

It soon became apparent, though, that Magoro Hill had a much more complicated settlement history, which implied that the glass trade beads retrieved from the site could not be summarily attributed to a nineteenth-century or colonial-period occupation. A site survey yielded a surface collection of Iron Age earthenware that can be assigned to six well-dated ceramic facies associated with African farming communities: Silver Leaves (c. AD 280450), Mzonjani (c. AD 450-750), Kgopolwe (c. AD 10301350), Mutamba (c. AD 1250-1450), Tavhatshena (c. AD 1450-1600) and Letaba (post-AD 1640) [14].

The steep slopes of Magoro Hill, an inselberg rising nearly $200 \mathrm{~m}$ above the surrounding plain (Fig. 2), are lined with numerous stone-walled terraces that buttress platforms for the erection of residential and other domestic structures. With the possible exception of the Middle Iron Age Kgopolwe facies, subsequent excavations of a number of these terraces, as well as middens and a cattle enclosure, produced no evidence of a pre-Letaba settlement on the hill. Charcoal from an iron-working area on the eastern slope of the hill, close to where the majority of Kgopolwe sherds were collected, yielded a radiocarbon date (Beta-324,071) of $720 \pm 30 \mathrm{BP}$ (2-sigma calibration: AD 1260-1290). No in situ dwelling structures associated with the Kgopolwe phase were, however, uncovered.

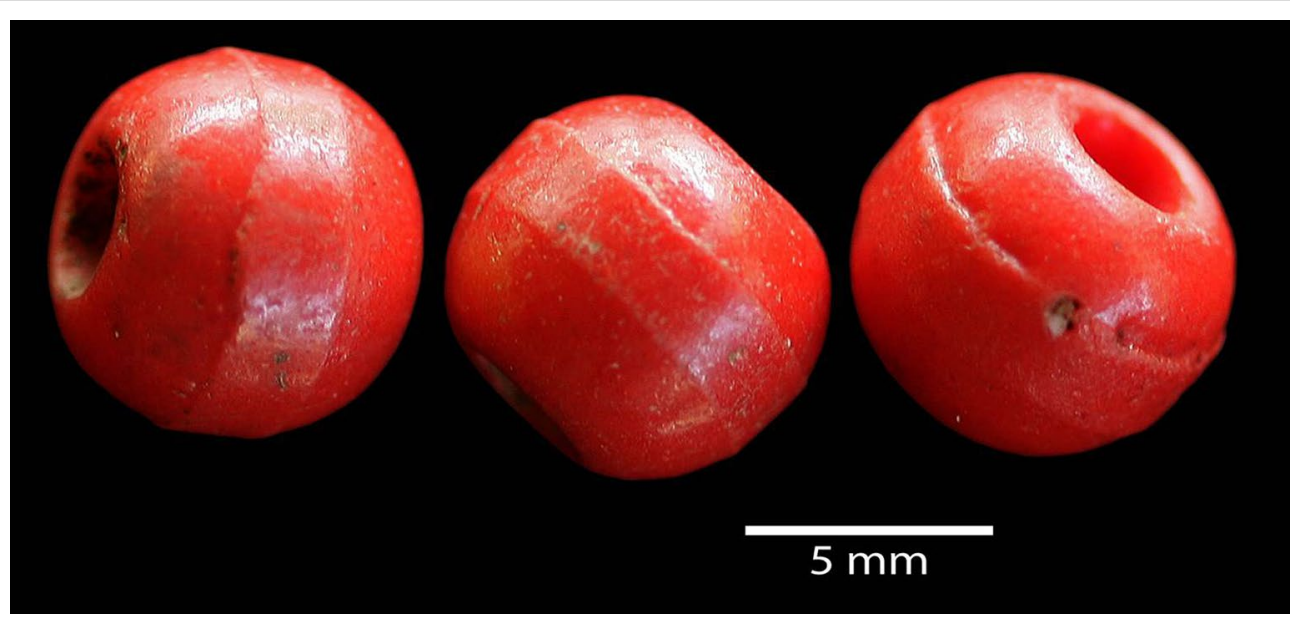

Fig. 1 Three beads coloured with nano- $(\mathrm{Zn}, \mathrm{Cd}) \mathrm{S}_{x} \mathrm{Se}_{\mathrm{x}-1}$ mixed crystals 


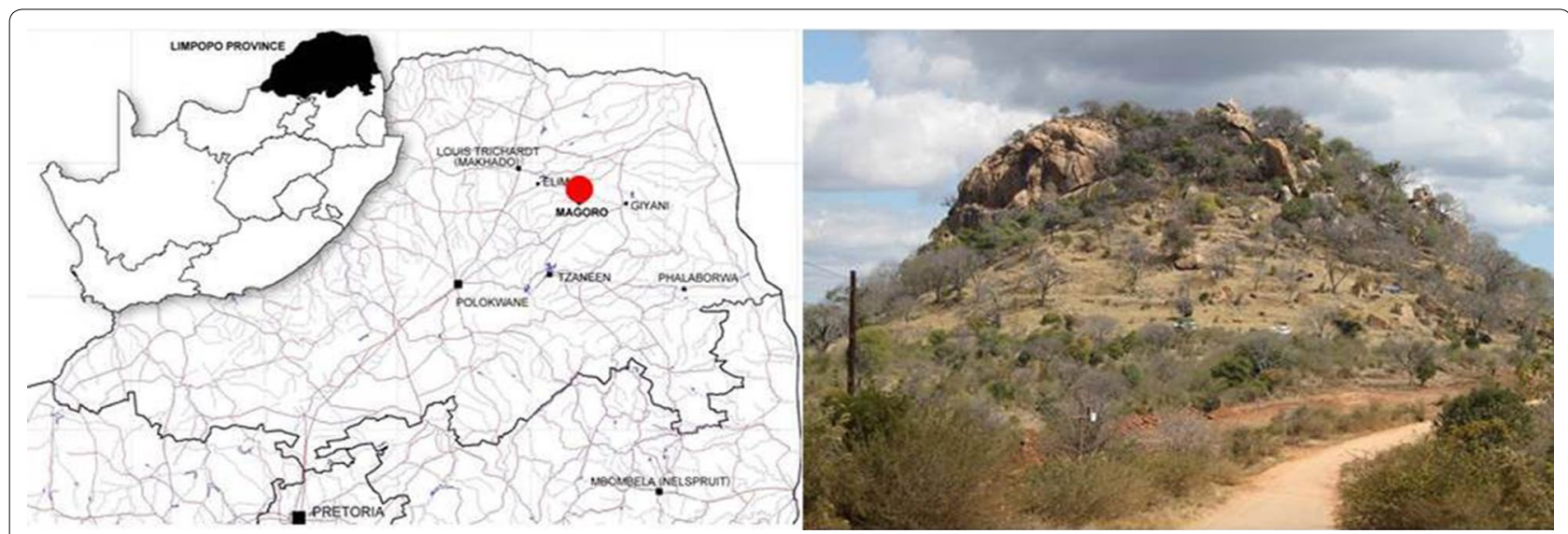

Fig. 2 Map indicating the location of Magoro Hill, Limpopo Province, South Africa (left). View of Magoro Hill from the southeast (right)

It is likely that Magoro Hill, similar to several other hills in northern South Africa, served as a location for episodic rainmaking rituals performed by African farmers $[15,16]$. This would account for the surface collection of sherds attributed to Early Iron Age (Silver Leaves and Mzonjani) and Middle Iron Age (Mutamba and, possibly, Kgopolwe) ceramic facies.

Likewise, we have not been able to confirm any permanent settlement associated with the Tavhatshena ceramics facies, which is ascribed to ancestral Venda speakers. It is noteworthy, though, that oral traditions allude that the site formed part of the domain of the Ngona, the ethnonym for an elusive aboriginal Venda grouping, before the Rambau-Singo Venda clan of Magoro conquered the area towards the end of the eighteenth century AD and ensconced themselves on the hill [17]. It became clear from the associated material cultural remains uncovered by the excavations that the stone walls and the terrace deposits can be principally associated with the Venda occupation of the site, in particular the Letaba facies. Burnt house floors associated with pole-andearth structures, dating to an August 1865 attack on the hill by a combined force of European settlers and African (Tsonga) auxiliaries, have preserved exceptionally well. During this encounter the Magoro chiefdom was almost wiped out. About 300 occupants, mainly adult males, were killed, while several women and 120 children were carried away, the former to be distributed among the Tsonga militia and the latter to be indentured to the Soutpansberg colonists as so-called 'apprentices' [18, 19]. A small and impoverished group of Magoro people returned to the hill in the late 1880s, where they remained till the 1950s, when they were relocated under duress by the South African government to make way for the Gazankulu 'homeland' for the Tsonga 'nation' [17]. During the post-1880s settlement phase the Magoro people mainly occupied the base of the hill except for a rectangular brick-built house, which was located higher up on the eastern side of the hill, probably to serve as the prestige dwelling of the then reigning chief. It was from a secure context inside this rectangular house that the selenium-coloured red beads referred to above was recovered [10]. No human settlement occurred on Magoro Hill after the 1950s.

Based on the complex history of Magoro Hill outlined above, it became clear that the glass bead assemblage could be derived from different periods of occupation or use of the site. Furthermore, as a result of the steep incline of the hill, soil deposits continually trickle downwards, especially during heavy rains or through the erosive impact of droughts, exacerbated by the movement of cattle and goats from nearby subsistence farmers who use the area for pasture. Most of the excavated terrace structures or features containing in situ cultural material were overlain by substantial soil deposits that had washed down or accumulated over many years. This stratigraphic quandary is compounded by the fact that glass beads are small and mobile and could easily filter deeper into underlying deposits, thus complicating an assessment of their contextual association. Additionally, it had to be considered that in order to gain entry into the existing lucrative bead trade market and to cater for the established preferences of African consumers, European beadmakers were obliged to emulate some of the beads that had earlier been imported from the East. Despite these caveats, a comparative analysis of the bead sequence from Magoro Hill potentially could shed new light on changing patterns in the availability, range, consumption and origin of glass trade beads imported into the northern interior of South Africa over many centuries.

In this paper we demonstrate the use and archaeological application of Raman and XRF measurements 
to separate earlier imported beads from later counterparts by identifying glass nanostructure, as well as pigments and opacifiers, which were not used in bead series pre-dating the sixteenth century AD. Recently we have developed a methodology combining visual classification based on morphology, X-ray fluorescence (XRF) and Raman spectroscopy to classify trade beads imported into southern Africa between the eighteenth and sixteenth centuries AD [6]. This methodology was based on our previous work on glass trade beads recovered from K2 and Mapungubwe Hill, the capital sites of southern Africa's first state complex in the Limpopo River Basin [20-22]. In studying the beads from Magoro Hill, we follow the same experimental procedures for classifying beads imported up to the seventeenth century $A D$ and extend this approach to beads imported after the seventeenth century, making use of the database compiled for more recent beads retrieved from Mapungubwe Hill. As has been shown, a substantial number of beads from the Mapungubwe Hill collection were found to postdate the heyday of the site's occupation in the first half of the second millennium $\mathrm{AD}$ and were European imports [21, 22].

\section{Materials and experimental techniques Raman measurements}

Raman spectra of the beads were recorded with three different Raman instruments, namely a HR Raman instrument (Horiba JobinYvon, France), a portable HE532 (Horiba JobinYvon, France) spectrometer and a T64000 Raman spectrometer (Horiba JobinYvon, France). Full details of the spectrometers and recording conditions can be found in Koleini et al. [6]. Procedures for baseline correction are also given in Koleini et al. [6]. Many of the annular and hexagonal European beads recovered from house floors had been affected by the fires that burnt down the thatched dwellings in the 1865 battle. Some of these beads were even melted and warped by the heat. Furthermore, some of the beads retrieved from terrace fills, which accumulated through down-slope erosion, and a midden/byre deposit, which extended more than a metre in depth, have corroded surfaces that could influence the results. In the case of severe corrosion several spectra had to be recorded before a spectrum representative of the glass could be obtained and in some instances the corrosion layer was removed on small spots.

\section{XRF measurements}

A portable Thermo Scientific Niton XL3t GOLDD spectrometer was used for the quantitative X-ray fluorescence (XRF) measurements of the selected glass beads. This model is equipped with an Ag anode X-ray tube and a Geometrically Optimized Large area Drift Detector
(GOLDD). The X-ray tube is capable of $50 \mathrm{kV}$ maximum voltage, $200 \mu \mathrm{A}$ current and $4 \mathrm{~W}$ power. The samples were directly positioned on the analysis window of the Niton XL3 portable test stand due to the small size of the samples. Analyses were carried out using the fundamental parameters calibration that is employed in Mining $\mathrm{Cu} / \mathrm{Zn}$ modes. Four available elemental ranges, namely main, low, high and light with measurement duration of $100 \mathrm{~s}$ each, were applied to detect any trace of 36 elements from $\mathrm{Mg}$ to $\mathrm{U}$. The limit of detection of elements (LOD) was calculated using 3 sigma. The concentration of elements in each sample was reported in weight percent (wt\%). The total weight of the detected elements was subtracted from the weight of the sample, which gave the weight percent of elements not detected by the instrument (those with lower atomic mass than $\mathrm{Mg}$ such as sodium and oxygen).

In order to validate the results obtained using our instrument we analysed beads from each series curated in the Van Riet Lowe (VRL) bead collection housed at the University of the Witwatersrand. These beads were classified by Marilee Wood on morphological parameters and analysed by Robertshaw [23]. Marilee Wood also made available datasheets of the chemical composition of some beads in each series. We compared our data with these, as well as with the XRF data of the Mapungubwe Oblates in reference 20 and our results exhibited the same trends of all the elements discussed in the text (see Additional file 1: Table S1).

\section{Energy dispersive spectroscopy (EDS)}

One large yellow bead (Mag-k-y5), the Raman spectrum of which varied as a function of the analysed spot, was sliced using a Struers Minitom Diamond disk to obtain a cross section. A JEOL JSM 55 10LV SEM microscope coupled with a 500 Digital Processing XRF system was used for local analysis and to obtain an elemental distribution map of the bead cross section.

\section{The samples}

Beads recovered from archaeological sites in southern Africa have been studied by various researchers over a long period of time, each of them naming the beads according to different criteria. Some names are related to the place where the beads were excavated, some to the presumed place of production or even trade routes that brought the beads to Africa. This has resulted in more than one name for the same bead series in the literature (see reference 21 for more details). In order to avoid any confusion, we follow the classification system developed by Wood [5] for beads traded in southern Africa before the seventeenth century AD (see Table 1 for series name 
Table 1 Bead series classification based on morphological attributes and elemental analysis [23]

\begin{tabular}{ll}
\hline Bead series & Period traded in southern Africa \\
\hline Zhizo & Eigth to mid-tenth c. AD \\
K2 Indo-Pacific & Late tenth to early thirteenth c. \\
East Coast Indo-Pacific & Early eleventh to mid-thirteenth c. \\
Mapungubwe oblate series & Thirteenth c.- - second quarter to end \\
Zimbabwe series & Fourteenth to early fifteenth c. \\
Khami series & Fifteenth to seventeenth c. \\
\hline
\end{tabular}

and time period traded into southern Africa). Other beads are broadly classified as European as more research is necessary before an appropriate system can be worked out to assign names to all the types of beads imported after the seventeenth century. Some of the European beads, which have acquired colloquial names such as "white hearts", "slave beads", "Russians", "Dutch" or "Dogons", can be used as broad temporal markers based on historical production and trade records $[4,8]$.

A total of 1557 beads were recovered from the excavations on Magoro Hill. They were provisionally classified according to morphological attributes into seven bead series, namely 19 Zhizo (Z), 17 K2 Indo-Pacific (K2), 78 East Coast Indo-Pacific (EC-IP), 148 Mapungubwe (Map), 14 Zimbabwe (Zim), 40 Khami Indo-Pacific (K) and 1241 European (Eu) beads. From these tentatively grouped series, a sample consisting of 97 beads was selected for further analyses with the aim of verifying their classification. The selection focused on beads where assignment to specific bead series might be problematic. The analysed sample included mainly beads made of black, blue, green, yellow and white glass. After Raman analyses a further 61 beads were selected for XRF analyses. It was assumed that beads with matching morphology and Raman spectra are the same, in which case one representative bead was selected. The samples were labelled according to the site of origin, Magoro Hill (Mag), followed by the name of series mentioned above, the colour of the bead in abbreviation and sample number $(1,2,3 \ldots)$. For example, a light blue bead morphologically classified as Zimbabwe series was tagged as Mag-zim-lb9.

\section{Raman and XRF measurements of the glass matrix and pigments}

The Raman spectrum of glass consists of two broad bands, one around $500 \mathrm{~cm}^{-1}\left(\mathrm{SiO}_{4}\right.$ bending vibrations), and one around $1000 \mathrm{~cm}^{-1}\left(\mathrm{SiO}_{4}\right.$ stretching vibrations). In applying the procedure developed in Koleini et al. [6], the first step is to compile a graph in which the wavenumber maxima of the bending $\left(\delta_{\max } \mathrm{Si}-\mathrm{O}\right)$ and stretching $\left(v_{\max } \mathrm{Si}-\mathrm{O}\right)$ Raman bands in the spectra recorded of the beads under study are plotted against each other (Fig. 3). This method was previously used to study glass trade beads from southern Africa [6, 21, 22].

The results of the Raman analyses are presented in Fig. 3. Four groups of beads were distinguished: (A) black beads coloured with high concentrations of the Fe-S chromophore; (B) beads made of soda glass; (C) beads made of soda-lime glass and (D) glass containing high amounts of lead. Group C contains a subgroup, namely plant ash glass, where calcium and sodium were added in the form of plant ashes rich in these elements. As technology improved plant ash was replaced by industrial chemicals resulting in soda-lime glasses where magnesium and potassium, typical of plant ash glass, are absent. It is immediately clear that not all the beads in the study gave spectra that accorded with the series into which they had been morphologically classified. The majority of the beads belong to Group $\mathrm{C}$, classified as soda-lime glass. As will be shown, a large number of the beads represented in Fig. 3 were mostly reassigned to the European bead series based on their chemistry (see Figs. 5 and 6 with beads marked $\mathbf{X}$ ).

In Fig. 4a, b typical Raman spectra of the beads that were used to compile the data presented in Fig. 3 are shown. The Raman classification into the soda and sodalime groups depends on the wavenumber position of the bending $\left(\delta_{\max } \mathrm{Si}-\mathrm{O}\right)$ band in the spectrum, where the most intense peak in the region $440-560 \mathrm{~cm}^{-1}$ is used for the $\mathrm{x}$-axis of the plot. In many instances the wavenumber position of the most intense peak is clear-cut, e.g. spectra $\mathrm{a}$ and $\mathrm{b}$ in Fig. $4 \mathrm{a}$, but in spectrum $\mathrm{b}$ in Fig. 4b the peaks have similar intensities and the division is more problematic. Since the shape and position of the bands are not only influenced by the glass structure but also by the presence of pigments and opacifiers, confirmation of the Raman division based on glass type with XRF measurements is advisable. Raman analyses of the postsixteenth-century beads from Mapungubwe Hill identified opacifiers and pigments (e.g. antimony, arsenates, lazurite, etc.), which are useful indicators of provenance and production period for beads arriving in Africa during the last 400 years [21, 22, 24]. Raman spectra recorded of pigments and opacifiers in this study are presented in Fig. $4 \mathrm{c}$ and $\mathrm{d}$.

\section{Beads classified as Indo-Pacific beads (Fig. 5)}

Indo-Pacific beads in general are made of mineral soda and characterised by high aluminium levels (mean $\mathrm{Al}_{2} \mathrm{O}_{3}: 13 \%$ ), the presence of uranium traces $(84 \pm 59 \mathrm{ppm})$, as well as low calcium (mean $\mathrm{CaO}$ : 2.85\%) and magnesium levels (mean MgO: 0.59\%) (see Additional file 1: Table S2) [23]. The beads classified as 


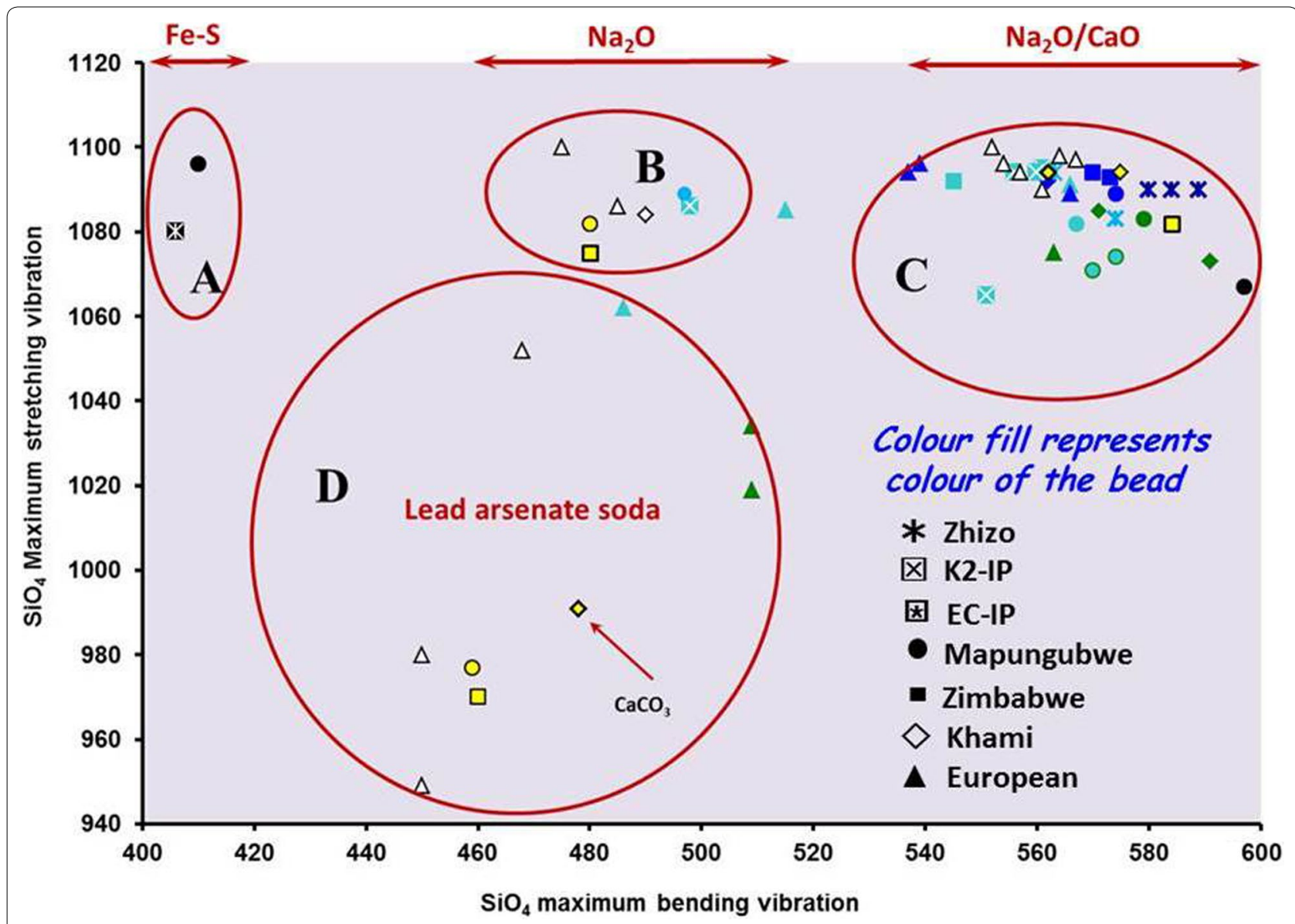

Fig. 3 Plot of the wavenumber maxima of the bending $\left(\delta_{\max } \mathrm{Si}-\mathrm{O}\right)$ and stretching $\left(\mathrm{v}_{\max } \mathrm{Si}-\mathrm{O}\right)$ bands of the Raman spectra of the beads classified according to morphological parameters. Colour fill represents the colour of the beads

Indo-Pacific based on morphological features are shown in Fig. 5 and are subdivided into K2, East Coast and Khami Indo-Pacific (K2-IP, EC-IP and K-IP) beads.

Indo-Pacific beads should all fall in Group B (Fig. 3) as they are made of soda glass. However, it has previously been shown that the resonance-enhanced Raman spectrum of the "Fe-S" chromophore, with a strong band at $\sim 415 \mathrm{~cm}^{-1}$ superimposed on the $\mathrm{SiO}_{4}$ bending vibrations around $500 \mathrm{~cm}^{-1}$ of the glass spectrum [20, 22], causes the formation of a separate group (A) consisting of black beads with Raman spectra mostly independent of glass structure [20]. Although East-Coast Indo-Pacific beads can be opaque black and brownish-red or translucent yellow, soft orange, green and blue-green, only black EC-IP beads were identified based on morphology. As they are coloured with the Fe-S chromophore their Raman spectra should place them in Group A (Fig. 3). Two black beads classified as EC-IP (b1 and b2) fulfil this requirement, corroborated by XRF data showing a high aluminium content and significant uranium traces typical of IP beads (Table 2). The chemical composition of both beads can fit either K-IP or EC-IP profiles as seen in Additional file 1: Table S2, where quite a large variation of compositions are indicated. However, on morphological grounds b1 is larger than b2 and in general K-IP beads tend to be larger than EC-IP beads. Also b1 contains higher calcium and lower potassium levels indicative of the K-IP series [25]. These two factors reclassify b1 as $\mathrm{K}-\mathrm{IP}$ and $\mathrm{b} 2$ as EC-IP. Another black pigment was identified in bead Mag-ecip-b3 with strong Raman peaks at ca. 470 and $600-630 \mathrm{~cm}^{-1}$ and a weak peak at $320 \mathrm{~cm}^{-1}$ (Fig. 4b, c) typical of the spinel jacobsite $\left(\mathrm{Mn}^{2+} \mathrm{Fe}_{2}{ }^{3+} \mathrm{O}_{4}\right)$ or other manganese containing spinel. Manganese/ iron oxides have previously been identified as pigment in glass trade beads excavated at Mapungubwe [21, 22, 26], the Democratic Republic of the Congo [27], Mayotte Island [28] and black glass of an Islamic multi-coloured bead found at Mapungubwe [23]. This specific bead was not analysed with XRF and therefore does not occur in Table 1, but since it has the same Raman spectrum (jacobsite) as two black beads (Mag-map-b1 and b2) wrongly classified as Mapungubwe Oblates based on 

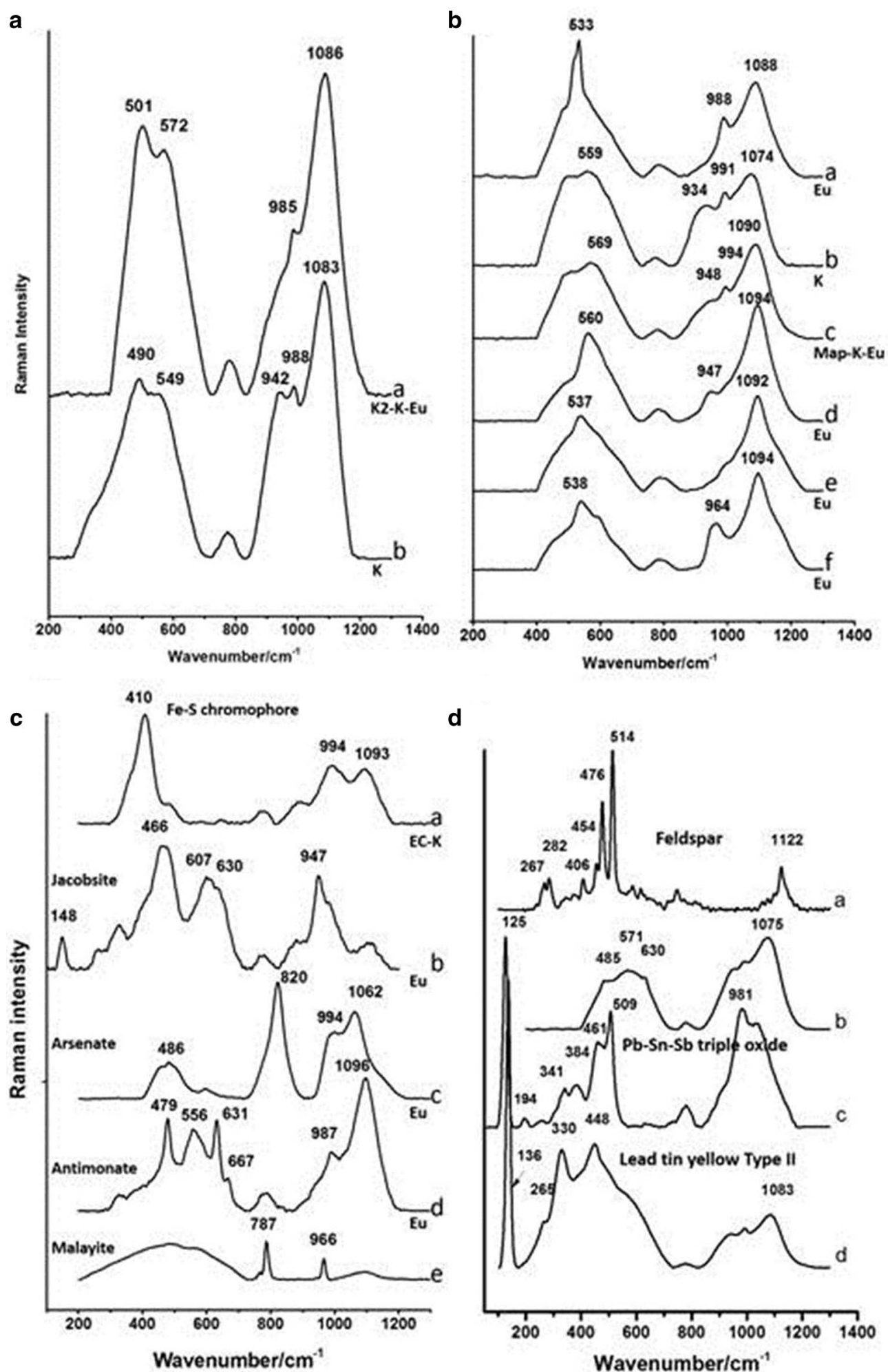

d

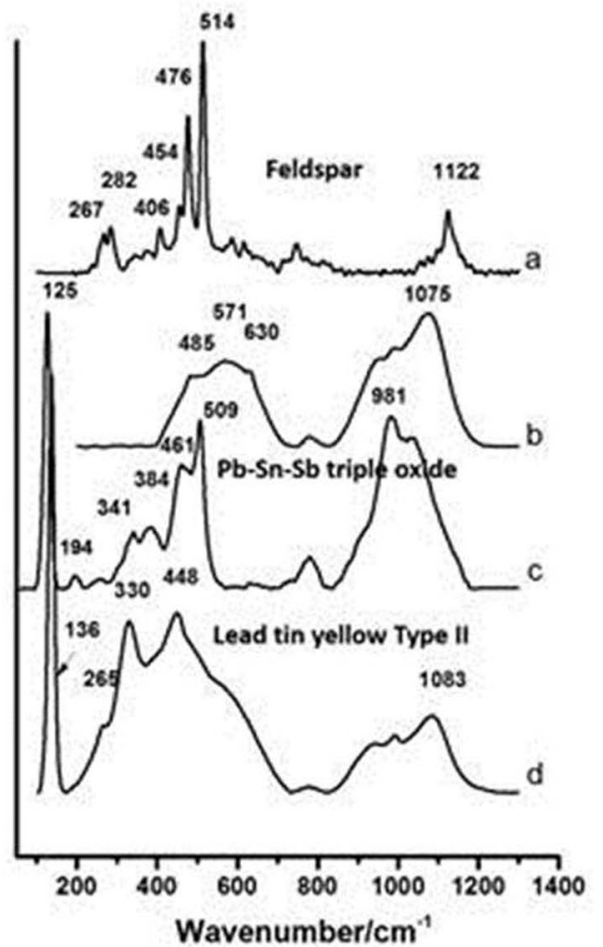

Fig. 4 Representative Raman baseline subtracted spectra of beads that fall into a the soda glass group and $\mathbf{b}$ the soda-lime group (top). $\mathbf{c}$, d Pigments and other crystalline phases identified through their Raman spectra (bottom) 

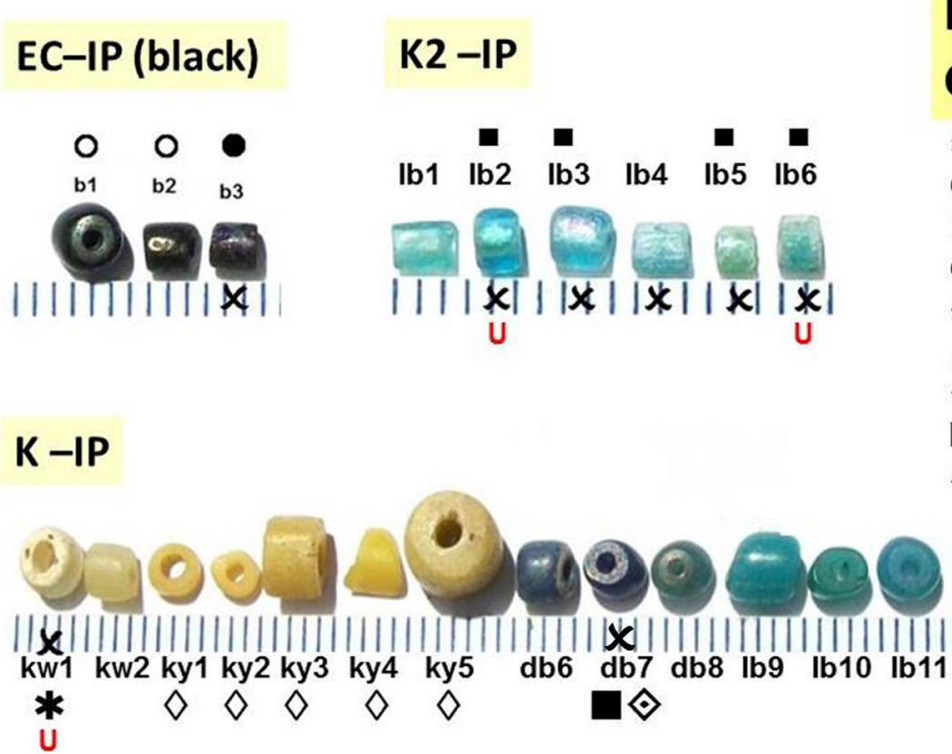

Indo-Pacific beads Group B

* Lead arsenate soda glass.

O Fe-S chromophore.

- Calcium antimoniate.

- Jacobsite.

$\checkmark$ Lead tin yellow type (II).

$\Delta \mathrm{Cu}+$ lead tin yellow (II).

$\diamond \mathrm{Co}+\mathrm{As}\left(\mathrm{Co} / \mathrm{As}^{\sim} 2\right)$.

- Tin oxide.

x Incorrectly classified.

Fig. 5 The beads from Magoro Hill that were tentatively classified on morphological grounds as Indo-Pacific beads (see Wood [2]). Pigments or opacifiers that were identified in the beads using Raman or XRF measurements are indicated. Beads incorrectly classified are indicated with $\mathbf{x}$. Beads reclassified based on the absence or low Uranium content are indicated with a $U$

their morphology (Fig. 6), it is assumed that it has the same glass structure with low $\mathrm{Al}$ (mean $3 \%$ ) and $\mathrm{K}$ (mean $1.1 \%$ ) concentrations (Table 3 ). This glass composition is similar to some of the other beads originating from Europe so all three beads coloured with jacobsite are reclassified as European. (See Additional file 1: Table S3 for summary of re-classification).

Typical K2 Indo-Pacific (K2-IP) beads are made of mineral soda and belong in Group B (Fig. 3). In colour they range from transparent to translucent blue-green to light-green and are drawn beads with a tubular form (diameter 2-3.5 mm, length: 1.4-4 mm) [2]. Although the beads classified as K2-IP (Fig. 5) fit the morphological requirements, only one of the beads (Mag-k2-lb1) gave a Raman spectrum that places it in Group B. XRF measurements (Table 2) confirm that this bead is made of soda glass and its uranium (10.1 ppm) and aluminium (Al 7.63\%) content also complies with that of K2-IP beads (U: $68 \pm 68$ ppm, mean $\mathrm{Al}_{2} \mathrm{O}_{3}: 11.8 \%$ ) [24]. The Raman spectra of the other beads place them in the soda-lime group, confirmed by XRF measurements ( $\mathrm{Al}$ too low, $\mathrm{Ca}$ too high, absence of uranium and the presence of small amounts of antimony (Sb) and arsenic (As) probably added as opacifiers) and therefore they can be assigned to the European period. (See Additional file 1: Table S3 for summary of re-classification).

Khami Indo-Pacific (K-IP) beads are drawn and can be opaque (black and brownish red) or translucent bluegreen, green, yellow, orange, cobalt blue and off-white.
Their shapes vary: most are irregular cylinders in sizes medium to large (3.5-5 mm diameter) [2]. K-IP beads are distinguished from the other IP beads by very high uranium counts $(189 \pm 100 \mathrm{ppm})$ and also higher $\mathrm{Na}_{2} \mathrm{O}$, (mean 18.66\%), $\mathrm{CaO}$ (mean 3.39\%), MgO (mean 1.21\%) and $\mathrm{Al}_{2} \mathrm{O}_{3}$ (mean 9.81\%) levels [23]. Only one Khami classified bead (white) falls into the soda-glass group (Mag-k-w2) according to its Raman spectrum (Fig. 3). The earliest white beads in the archaeological record of southern Africa are slightly translucent, off-white Khami beads for which Robertshaw [23] could not determine a specific pigment. Mag-k-w2 fits this description as we could also not identify any pigment. From 11 Khami beads analysed with XRF, the absence of uranium in three (kw1, g12, r16) and high lead and arsenate in g14 confirm that they do not fit the elemental composition profile for the Khami-IP series (Fig. 5). Based on glass composition g12 belongs in the Map/Zim series, kw1 and g14 contain calcium antimoniate and lead arsenate respectively and are therefore of European origin and r16 is made of a low aluminium European glass. Db7 is an exception that cannot be placed in a known glass series as its glass composition is close to the IP series but the presence of calcium antimoniate (very low concentration, $0.001 \mathrm{ppm}$ ) indicates an European origin. The remaining six beads analysed with XRF (kw2, y1, y2, db8, lb11, g13) have similar compositions as Khami-IP beads in the concentration of both main and trace elements. One of the beads (ky5) is inhomogeneous in composition (made of recycled 


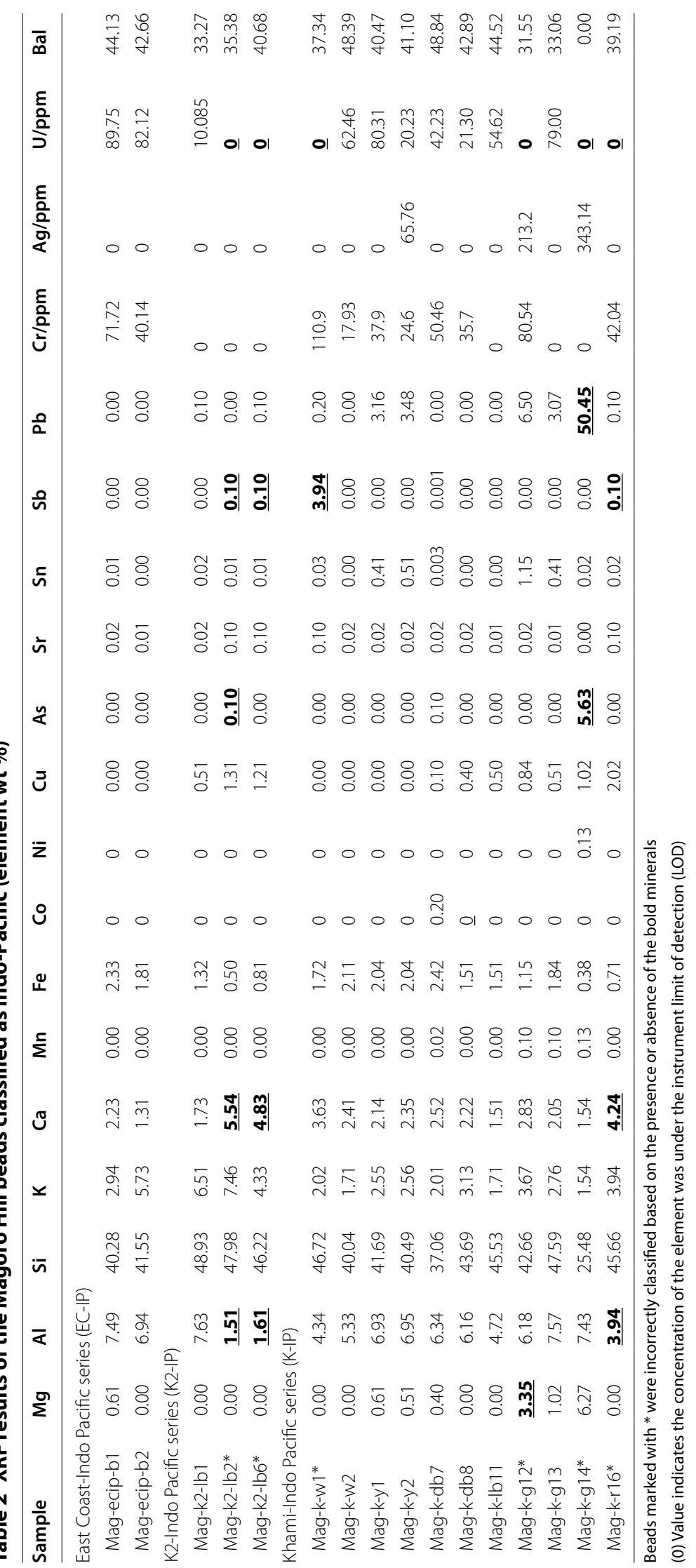




\section{Zhizo series}

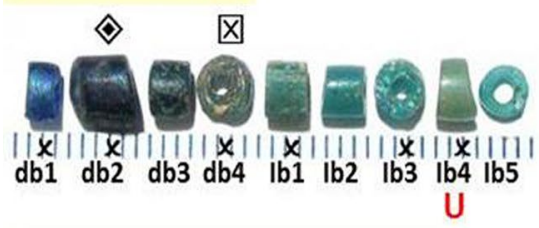

Mapungubwe Oblates

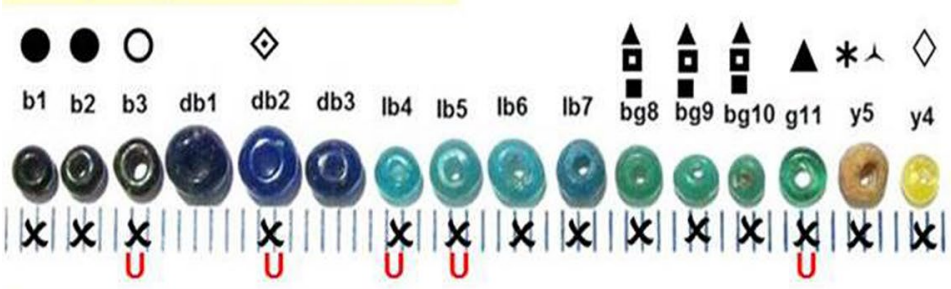

\section{Zimbabwe series}

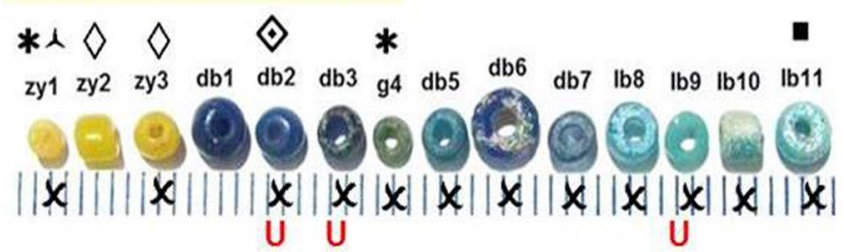

Plant ash glass Group C

* Lead arsenate soda glass.

O Fe-S chromophore.

冈 Malayite

$\triangle \mathrm{Pb}-\mathrm{Sn}$-Sb triple oxide.

- Calcium antimoniate.

- Jacobsite.

$\diamond$ Lead tin yellow type (II).

$\Delta \mathrm{Cu}+$ lead tin yellow (II).

$\diamond \mathrm{Co}+\mathrm{Ag}$ (Germany).

$\diamond \mathrm{Co}+\mathrm{As}\left(\mathrm{Co} / \mathrm{As}^{\sim} 2\right)$.

- Tin oxide.

$\mathbf{x}$ incorrectly classified

Fig. 6 The bead series that were identified on morphological grounds as plant ash series beads (Wood [2]). Pigments or opacifiers that were identified in the beads using Raman or XRF measurements are indicated. Beads incorrectly classified are indicated with $\mathbf{X}$. Beads reclassified according to the presence of Uranium are indicated with a $U$

glass - see later). Db6, lb9, lb10 and lb15 were not analysed with XRF and have similar Raman spectra as lb11 (Khami-IP series) so we believe the Khami classification is correct. The placement of most Khami classified beads in the soda-lime group (C) (Fig. 3) despite similarity in composition to those in the soda group can possibly be due to recording Raman spectra on areas where corrosion has occurred. As the XRF measurements for the Magoro Hill beads were done using a portable instrument, beads with uranium content slightly lower than 100 ppm were not excluded from the Khami group based on their uranium content. (See Additional file 1: Table S3 for summary of re-classification).

\section{Beads classified as plant ash glass (Fig. 6)}

Zhizo, Mapungubwe and Zimbabwe glass beads were made from plant ash glass [23] and belong in Group C in Fig. 3. These beads were generally made by adding plant ash as flux to silica-rich ingredients (e.g. sand) and are differentiated from the soda glass beads (IP series) by higher $\mathrm{Ca}$ and $\mathrm{Mg}$ content, lower $\mathrm{Al}$ and the absence of uranium. Zhizo series beads have lower aluminium content than the Mapungubwe and Zimbabwe series beads.

Zhizo beads are drawn cobalt, yellow, blue-green or green tubes and generally larger than the other plant ash beads $(2.5-13 \mathrm{~mm}$ in diameter and up to $20 \mathrm{~mm}$ long). All the beads classified as Zhizo fall in the sodalime group (group C) in Fig. 3, compatible with plant ash glass. However, XRF measurements of six of the beads, selected because they had different Raman spectra, show that they do not match Zhizo beads in composition. The absence of $\mathrm{Mg}$ in four beads (db1, db4, lb1, lb3) disqualifies them as plant ash glasses and the two that do contain magnesium are disqualified for other reasons. The high lead content and glass composition of Mag-z-db2 are compatible with some European classified beads (db21, lb25 and w8) and the cobalt colouring the bead is associated with silver, manganese, nickel and arsenic, similar to European classified beads (db21, db30, db31 and db32). This is in contrast to the cobalt colouring Zhizo beads with a higher ratio of $\mathrm{Co} / \mathrm{As}(>1)$ or cobalt associated with high iron and low manganese content $(\mathrm{Mn} / \mathrm{Fe}<0.1)$ as found in Jingdezhen glazes, both originating from east 


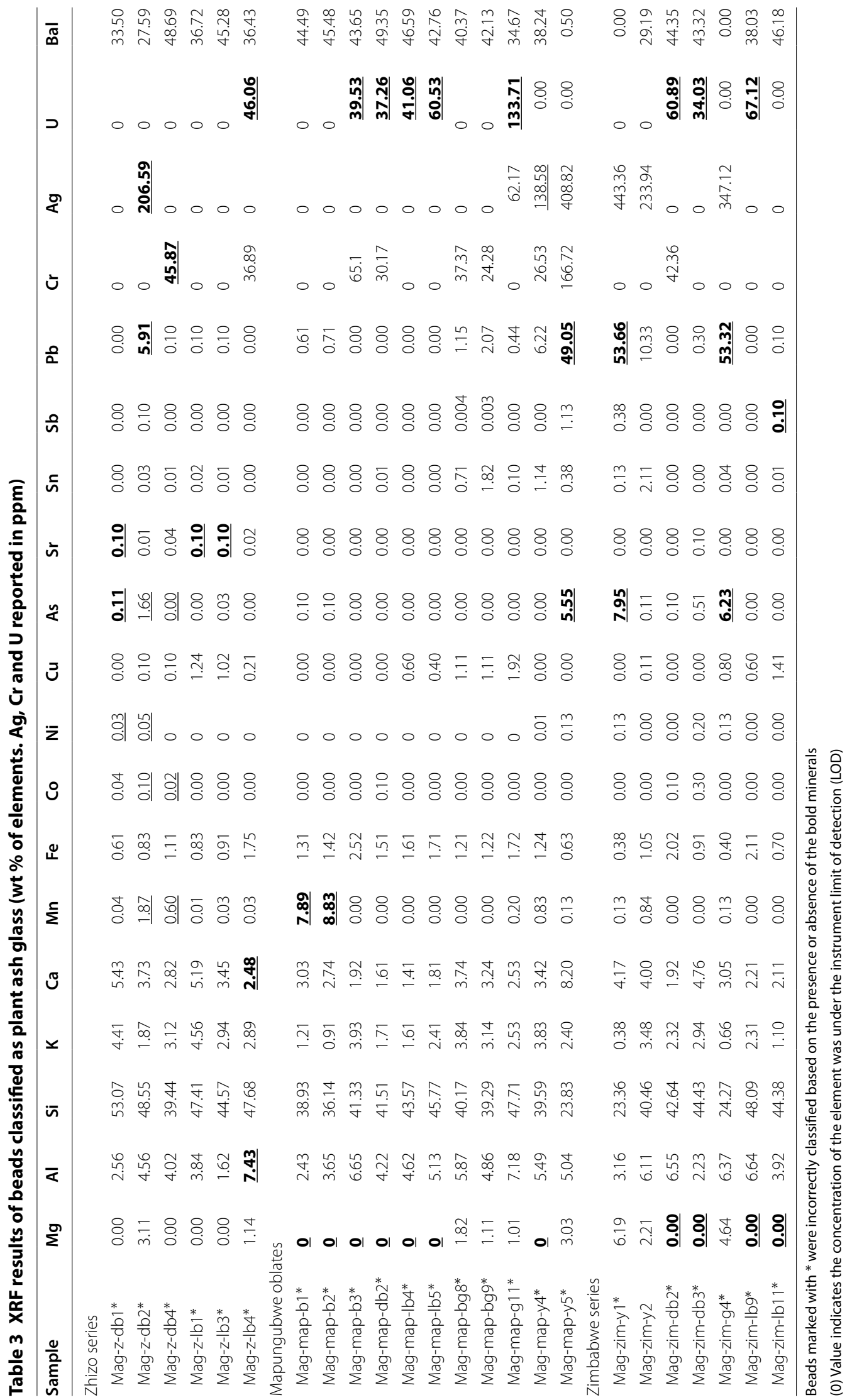


of the Euphrates [29, 30]. Mag-z-db4, a wound bead, contains high aluminium levels and malayite ( $\mathrm{Cr}$-Sn sphene), a phase also detected in some soda glass beads recovered at the Antsiraka Boira necropolis on Mayotte Island (twelfth-thirteenth century) [28]. The cobalt colouring this bead is associated with a high amount of Mn and the ratio of $\mathrm{Co} / \mathrm{Mn}$ is about 0.3 reported for cobalt minerals from Far East Asia (China and Vietnam) [31]. As not one of the beads analysed with XRF could be placed in the Zhizo series we assume that the three beads not analysed with XRF also have a European origin. (See Additional file 1: Table S4 for summary of re-classification).

The Mapungubwe Oblate bead series consists of translucent cobalt blue and plum beads (rare), as well as opaque black, bright yellow, orange, green and turquoise beads. Among these colours, green and turquoise beads contain tin oxide as an opacifier. They are uniformly small oblates (2-3.5 $\mathrm{mm}$ diameter) with heat-rounded edges and typically contain $\mathrm{MgO}(3 \%)$, $\mathrm{K}_{2} \mathrm{O}$ (3.8\%), $\mathrm{CaO}(4.7 \%)$ and $\mathrm{Al}(8.2 \%)$ [20]. Black beads are the most common and coloured with the Fe-S chromophore, but give distinct Raman spectra compared to EC-IP beads [20]. Two of the black beads classified as Mapungubwe Oblates are coloured with jacobsite, which reclassifies them as originating from Europe. The third black bead contains uranium, which implies that it is not made of plant ash glass but soda glass and can, therefore, be reclassified as a Khami bead. The glass chemistry of only two beads (Mag-mapbg8 and Mag-map-bg9) is similar to the Mapungubwe Oblates, but both are blue-green, in contrast to the very bright Mapungubwe Oblate yellow-green beads (see Fig. 1 in reference 20) coloured by mixing lead tin yellow type II, copper and tin oxide (Table 1a, reference 20 ). Both beads contain $\mathrm{Cu}$ and lead tin yellow type II but the presence of calcium antimoniate disqualifies them to be Mapungubwe Oblates. However, the high $\mathrm{Al}$ content suggests an Asian origin and therefore we could not classify these beads into one of the existing groups. As for the remaining beads, some lack Mg content, one falls into the lead arsenate group, five contain uranium and one bead is coloured with cobalt associated with silver, which disqualifies it since the cobalt colouring the Mapungubwe Oblates is associated with arsenic [20]. (See Additional file 1: Table S4 for summary of re-classification).

Zimbabwe series beads (size: $2-3.5 \mathrm{~mm}$ ), with a similar glass structure as the Mapungubwe Oblates, include translucent blue-green, blue, yellow, transparent dark green and opaque black cylinders and oblates [2]. They are made of plant ash glass (soda-lime group) and therefore contain no uranium and have higher levels of $\mathrm{CaO}$ (6.9\%) and $\mathrm{MgO}(4.3 \%)$ than the Indo-Pacific series [23].
Opaque beads should contain tin oxide. Only one bead (Mag-zim-y2) chemically fits into this classification. Three beads contain $\mathrm{Mg}$, but two of them have high $\mathrm{Pb}$ and As contents placing them in the lead arsenate group. The presence of uranium in two beads (db2, lb9) and antimony in one of the beads (lb11) classify them as Khami and European respectively. One of the beads (db3) is European due to the absence of $\mathrm{Mg}$, high uranium and low aluminium content of the glass that does not match with the pre-European series. (See Additional file 1: Table S4 for summary of re-classification).

It should be noted that the XRF results were obtained with a portable XRF instrument and the detection of lighter elements is not as accurate as for more sophisticated instruments. A low count of $\mathrm{Mg}$ should therefore not be the only criterion by which a bead should be eliminated as made of plant ash.

\section{Beads classified as European beads (Fig. 7)}

The beads that on morphological attributes did not fit into the above groups were loosely classified as of European origin. According to their Raman spectra, these beads are placed in Groups B, C and D and therefore can be made from soda glass (Group B), soda-lime glass (Group C) or a glass with high concentrations of lead ( 11-43 wt \%) and arsenic ( 4-13 wt \%), placing them in Group D (Fig. 3). The replacement of strong covalent bonded $\mathrm{Si}$ cations by ionic bonded $\mathrm{Pb}^{2+} / \mathrm{As}^{2+}$ leads to depolymerisation of the glass network causing the stretching massif to shift downwards to between 949 and $1072 \mathrm{~cm}^{-1}$. Most of the spectra of these beads also have a strong sharp peak at ca. $820 \mathrm{~cm}^{-1}$, a signature of arsenate in the composition (Fig. 4c) [32, 33]. The use of lead arsenate is associated with Venetian glassmakers who used this compound from the end of sixteenth century in the production of lattimo glass [34]. The very hazardous nature of working with volatile arsenic limited production to Venice and its use only increased after improving the production process during the mid-nineteenth century $[33,35]$. Therefore, these beads were probably only imported into southern Africa from the late nineteenth century AD. Group D mostly consists of beads morphologically classified as European in addition to a few beads classified as Mapungubwe, Zimbabwe and Khami (Figs. 5, 6, 7) due to similar morphological parameters. The amount of soda in these beads is low considering the non-detected elements' weight percentage (on average $5.4 \mathrm{wt} \%$ ). A representative Raman spectrum is seen in Fig. 4c.

White beads were coloured with calcium antimoniate $\left(\mathrm{CaSb}_{2} \mathrm{O}_{6}, \mathrm{CaSb}_{2} \mathrm{O}_{7}\right)$ (seventeenth c.) and lead arsenate (nineteenth c.), both pigments readily recognised through their Raman spectra [21, 22] and XRF. The pigment in 

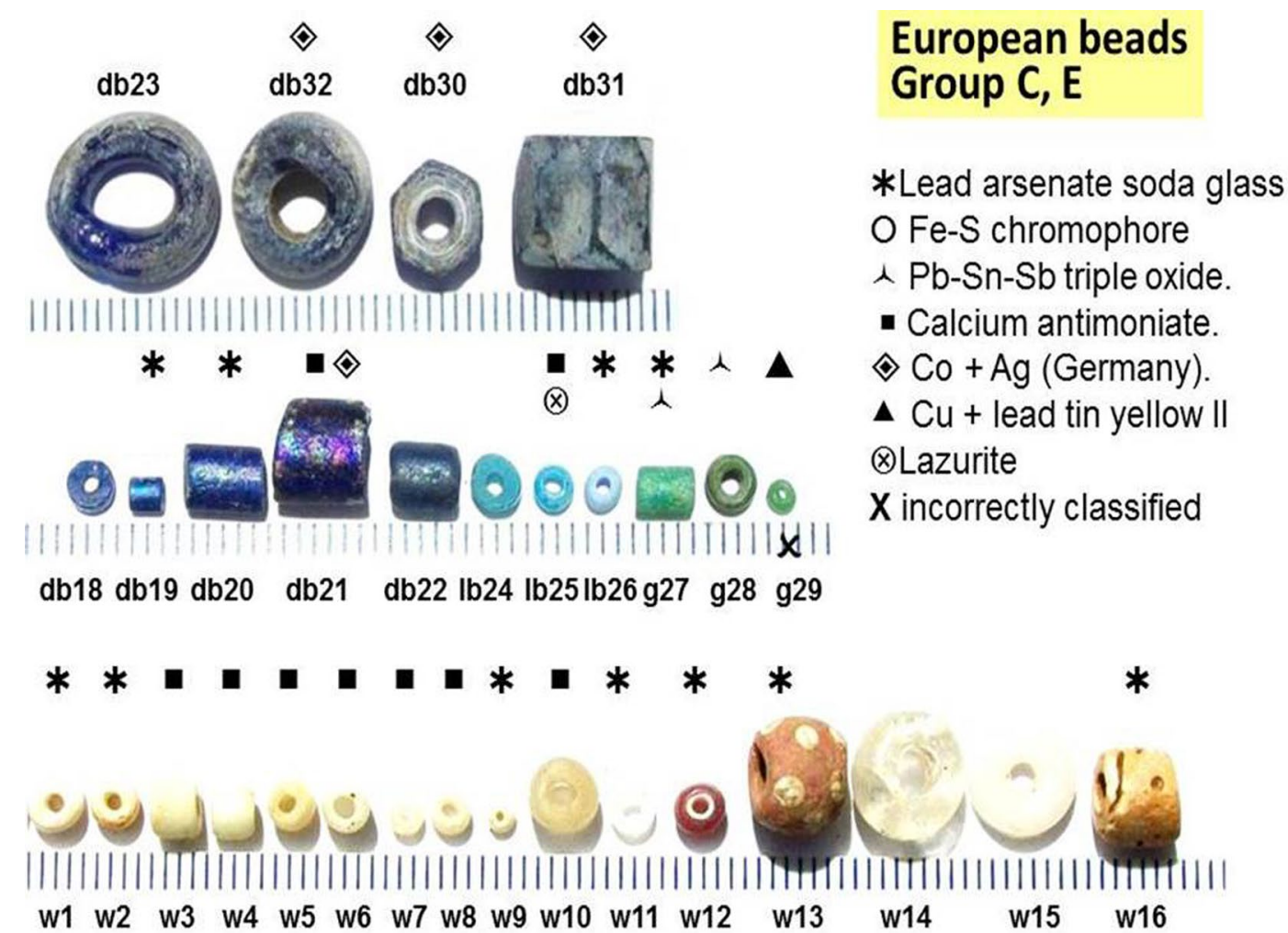

Fig. 7 European beads that on morphological grounds could not be assigned to the pre-sixtieth -century series beads (Wood [2]). Pigments or opacifiers were identified in the beads using Raman or XRF

the glass of the white dots on the large red bead ("fancy bead") and in the white core of the small red-on-white bead ("white heart") is lead arsenate, placing them in the same time period as the other arsenate-containing beads. One of the white beads (Mag-eu-w15) (Fig. 7) is actually a white button which was made by a Prosser moulded production process from 1840 onwards. They were made by moulding a mixture of feldspar or clay with quartz and other materials and compressing it under pressure i.e. a glass-ceramic. This is reflected in its spectrum that shows several sharp peaks at $476,514,1122 \mathrm{~cm}^{-1}$ corresponding to a mixture of feldspars (Fig. 4a, d).

The large faceted hexagonal beads, which were made in Bohemia (Czechoslovakia), as well as the single-wound annular (ring) beads mainly made in Germany (top row Fig. 7), appeared in southern Africa in the nineteenth century and are therefore useful chronological markers [2]. It would appear from contemporary documentary records that annular and hexagonal beads were popular among the Venda in the 1860s. Known as tombo-la-Venda (literally: Venda stone), strings of annular beads constituted the most common bead type listed in the account book of Manuel de Gama (n.d), an Indian-Portuguese trader whose trading-post was located between Magoro Hill and Elim (see map, Fig. 1). In 1862 João Albasini, superintendent of 'native tribes' in the Soutpansberg, reported that four African carriers had been robbed and killed on a trading trip from Maputo into the South African interior. The stolen goods included 400 strings of annular ("matombo") beads, six bundles of annular ("matombo") beads, 300 bundles of small multi-coloured beads, as well as twelve bundles of faceted (hexagonal) beads [36]. The recovery of partly charred annular and hexagonal beads from the floor of a hut (MB11) destroyed during the August 1865 attack also testifies to their wide circulation in the region (Fig. 8).

It is noteworthy that the strong calcium phosphate peak at $958 \mathrm{~cm}^{-1}$, previously observed in the Raman spectrum of European-period hexagonal beads from Mapungubwe Hill [21], did not appear in the spectra of hexagonal beads from Magoro Hill. This is a clear indication that there was more than one origin for the beads as also mentioned by Van Riet Lowe [37]. XRF results show these beads are potash-lime glass with potassium content between 7.5 and $12.3 \%$. (Note that potassium-based glass continued to be produced in England up to the mid 19th century, although soda glass were produced in other parts of Europe beacause of the 


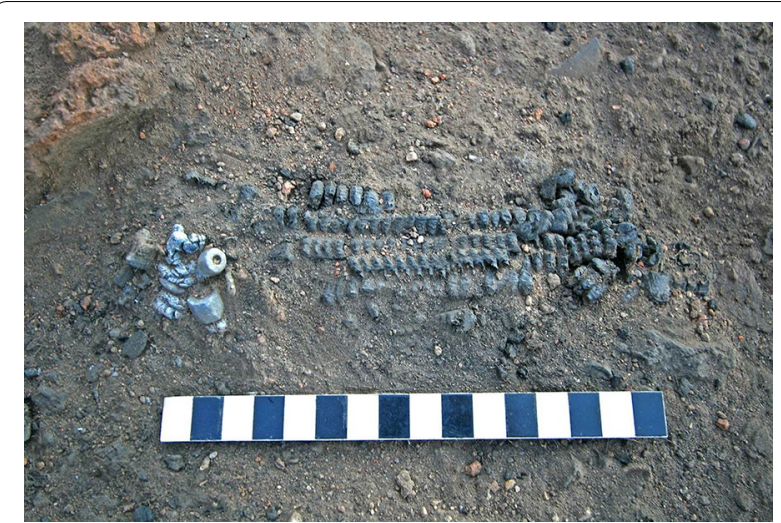

Fig. 8 Glass beads and a maize cob retrieved from the floor of a hut that burnt down during the attack on Magoro Hill in August 1865

availability of Leblanc and then Solway soda.) Cobalt, associated with silver (Ag), was detected as colourant in these beads. The source of cobalt is most probably from the Erzgebirge in Saxony [24, 38, 39]. Based on trace elements, four different sources of cobalt can be assumed for blue beads. More research is, however, needed to differentiate between the wide range of beads imported from Europe and to determine their respective centres of production. The XRF analyses of these beads are available in Table 4.

One of the light blue beads (Mag-eu-lb25) is coloured with lazurite/ultramarine (Fig. 4a, b) and opacified with antimony. Lazurite in the form of natural mineral was detected in Islamic ceramic glazes and glass from the thirteenth-fifteenth century AD [40] but the synthetic form (ultramarine) was only in use since 1828 in Europe [41]. It is not possible to discriminate between the natural and synthetic forms of the pigment with the laser lines used, but the glass that the bead (lb25) is made of has a high lead content (7.2\%) which differentiates it from the earlier beads series (before seventeenth century) from south Asia and the Middle East and is more similar to beads from the European series (Mag-eu-db21 and Mag-eu-w8) with low lead content. Mag-eu-db1 is a low aluminium and high calcium glass with cobalt used as colourant. The associated elements with cobalt are nickel, arsenate $(\mathrm{Co} / \mathrm{As}=0.4)$ and bismuth (432.69 ppm), while cobalt blue from east of the Euphrates (such as cobalt in Zhizo beads) shows a higher ratio of $\mathrm{Co} / \mathrm{As}(>1)$ or is associated with a high iron and low manganese content $(\mathrm{Mn} / \mathrm{Fe}<0.1)$ as found in Jingdezhen glazes [29, 30]. Mag-eu-lb1 and Mag-eu-lb3 have the same glass composition as

Table 4 XRF results of the beads classified as from European origin. The results reported in element wt \% except for $U$

\begin{tabular}{|c|c|c|c|c|c|c|c|c|c|c|c|c|c|c|c|c|c|c|}
\hline Sample & hg & Al & Si & $\mathrm{K}$ & $\mathrm{Ca}$ & $\mathrm{Mn}$ & $\mathrm{Fe}$ & Co & $\mathrm{Ni}$ & $\mathrm{Cu}$ & As & $\mathrm{Sr}$ & $\mathrm{Ag}$ & Sn & $\mathrm{Sb}$ & $\mathrm{Pb}$ & U/ppm & Bal \\
\hline & & & & & & & & & & & & & & & & & & \\
\hline lag-eu-w5 & & & & & & & & & & & & & & & & & & \\
\hline lag-eu-w7 & 0.00 & 2.21 & 52.01 & 3.52 & 3.52 & 0.00 & 0.60 & & 0.00 & 0.00 & & & & 0.00 & $\underline{0.50}$ & & 0.00 & 37.42 \\
\hline Mag-eu-w8 & 0.00 & 2.25 & & 1.84 & & 0.00 & 0.61 & 0.00 & .00 & 0.00 & 0.00 & 0.05 & 0.02 & 0.00 & $\underline{2.56}$ & & & 8.49 \\
\hline Mag-eu-w10 & 161 & 303 & 49.19 & 4.13 & 5.44 & 0.00 & 50 & $0 \cap 0$ & 0.00 & 0.00 & & 0.03 & & .00 & $\underline{0.30}$ & & & 4.78 \\
\hline lag-eu-w11 & 323 & 08 & 33.33 & 7.84 & & & & & 12 & & & 0.00 & & & .00 & & & 5.34 \\
\hline Mag-eu-w12 & & & & & & & & & 0.00 & & & 0.00 & & $\underline{0.11}$ & $\underline{0.77}$ & & & 26.55 \\
\hline Mag-eu-w13 & 4.57 & 3.28 & 25.67 & & 5.39 & 0.12 & & 0.00 & 0.00 & 0.00 & & 0.00 & & 0.00 & $\underline{0.47}$ & & & 25.09 \\
\hline Mag-eu-w14 & 040 & 112 & 47.43 & 2.82 & 2.72 & 0.00 & 0.20 & 0.00 & 0.00 & 0.00 & & 0.00 & 0.00 & 0.00 & 0.00 & 0.00 & & 2.20 \\
\hline Mag-eu-w15 & 0.00 & 12 & 57.92 & 11.32 & 0.10 & 0.00 & 010 & 0.00 & 0.00 & 0.00 & 0 & 0.00 & 0.00 & .00 & .00 & 0.00 & & 2.44 \\
\hline s & & & & & & & & & & & & & & & & & & \\
\hline Mag-eu-lb24 & 0.00 & 3.82 & & & 1.91 & 0.00 & & & 0.00 & $\underline{0.60}$ & & 0.00 & 0.00 & 0.00 & 0.00 & 0.00 & & 41.05 \\
\hline Mag-eu-lb25 & 0.00 & 3.67 & 40.77 & 1.63 & 1.53 & 0.00 & 0.20 & 0.00 & 0.00 & $\underline{1.33}$ & 0.20 & 0.00 & 0.02 & 0.00 & $\underline{1.22}$ & 7.34 & 0.00 & 42.10 \\
\hline Mag-eu-lb26 & 7.41 & 3.23 & 27.72 & 4.78 & 0.72 & 0.12 & 0.12 & 0.00 & 0.12 & 0.00 & & 0.00 & 0.12 & 0.00 & 0.00 & & 0.00 & 1.79 \\
\hline Mag-eu-g27 & 6.30 & 5.91 & 30.46 & 1.16 & 1.54 & 0.13 & 0.26 & 0.00 & 0.13 & $\underline{0.77}$ & & 0.00 & 0.05 & $\underline{0.64}$ & $\underline{0.64}$ & & & 0.00 \\
\hline Mag-eu-g28 & 5.30 & 3.95 & 29.35 & 1.48 & 3.33 & 0.12 & 0.62 & 0.00 & 0.12 & $\underline{1.48}$ & 5.80 & 0.00 & 0.12 & $\underline{0.37}$ & $\underline{0.99}$ & $\underline{46.98}$ & 0.00 & 0.00 \\
\hline Mag-eu-g29* & 0.00 & 6.31 & 42.57 & 2.24 & 2.44 & 0.00 & 3.05 & 0.00 & 0.00 & $\underline{0.92}$ & 0.00 & 0.00 & 0.00 & $\underline{0.41}$ & 0.00 & $\underline{2.95}$ & 87.20 & 39.10 \\
\hline Mag-eu-db30 & 0.41 & 1.02 & 49.34 & 12.72 & 6.31 & 0.02 & 0.10 & $\underline{0.05}$ & $\underline{0.03}$ & 0.00 & $\underline{0.20}$ & 0.00 & $\underline{0.01}$ & 0.00 & 0.00 & 0.00 & 0.00 & 29.91 \\
\hline Mag-eu-db31 & 0.50 & 1.21 & 52.96 & 7.54 & 4.32 & 0.10 & 0.20 & $\underline{0.10}$ & $\underline{0.10}$ & 0.10 & $\underline{0.40}$ & 0.00 & 0.01 & 0.00 & 0.00 & 0.10 & 0.00 & 32.36 \\
\hline Mag-eu-db32 & 0.00 & 3.04 & 50.00 & 7.81 & 4.46 & 0.10 & 0.91 & $\underline{0.04}$ & $\underline{0.04}$ & 0.01 & $\underline{0.41}$ & 0.00 & 0.01 & 0.00 & 0.00 & 0.00 & 0.00 & 33.16 \\
\hline
\end{tabular}

The bold elements were used for classification of the beads and underline elements are pigments or colorants

Beads marked with * were incorrectly classified

(0) Value indicates the concentration of the element was under the instrument limit of detection (LOD) 
Mag-eu-db1 and some of the white European beads (Mag-eu-w5-7-10) without $\mathrm{Ni}, \mathrm{As}$, and $\mathrm{Bi}$ that are associated with cobalt. These beads all contain low Fe, Ti and high Sr (Table 2).

Raman spectra of the glass assigned EC-IP (only 1 black), K2-IP (only 1 light blue), and Zim beads to the correct groups in Fig. 3. European beads were scattered in more than one group in accordance with a variety of origins, but the placement of Khami beads in both the soda and soda-lime groups reflects uncertainty as to their common origin. However, a ternary diagram plotting the aluminium content ( $\mathrm{Al}$ high for Indo-Pacific series), magnesium and potassium content (indicative of plant ash glass) and calcium content against each other shows a very small scattering between the Khami beads (Fig. 9), confirming a common source. Although the quantity of EC-IP (only 1 black), K2-IP (1) and Zim (2 yellow and green) beads (Zhizo and Mapungubwe Oblates not present) was small, they are in the correct groups in Fig. 9.

\section{SEM-EDS analysis of bead Mag-k-y5}

A yellow Khami bead (Mag-k-y5) in Group C contains calcium carbonate inclusions (Fig. 10a, zone 3) similar to those previously detected in a Khami bead with high $\mathrm{CaCO}_{3}$ content that was made of different kinds of glass through a recycling process. In order to test the generality of this observation we analysed this bead using SEM-EDS.

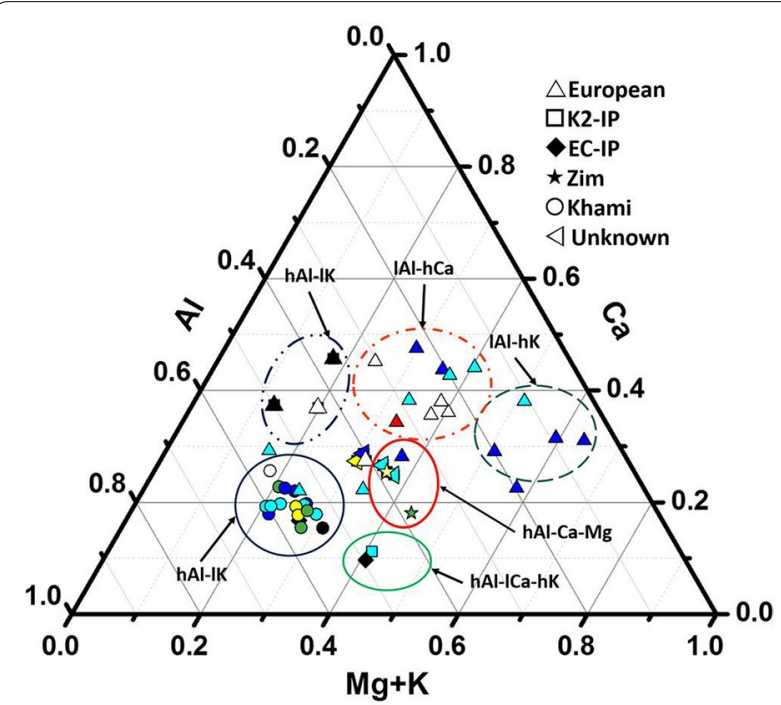

Fig. 9 Ternary diagram of all the glass beads analysed with XRF, plotting the aluminium content (Al high for Indo-Pacific series), magnesium plus potassium content (indicative of plant ash glass) and calcium content against each other. The type of bead indicated is after reclassification
The EDS results of bead Mag-k-y5 confirmed that it is inhomogeneous. The SEM image and SEM mapping of potassium in Fig. 10 show that a K-rich phase welds the pristine grains of other glass types together. Further EDS analyses of three spots on the cross section of the bead show the presence of soda glass in addition to calciumpotash glass. The ratio of elements $(\mathrm{K} / \mathrm{Na} / \mathrm{Ca} / \mathrm{Si})$ was found to vary depending on the spot sampled, namely:

Spot 1: $14.8 \% \quad \mathrm{~K} / 9 \% \mathrm{Na} / 29.5 \% \mathrm{Ca} / 46.4 \% \mathrm{Si}$ calciumpotassium glass;

Spot 2: $24.8 \% \mathrm{~K} / 5.3 \mathrm{Na} / 28.9 \% \mathrm{Ca} / 41 \% \mathrm{Si}$ calcium-potassium glass;

Spot 3: $4.9 \% \mathrm{~K} / 33.7 \% \mathrm{Na} / 6.2 \% \mathrm{Ca} / 55.2 \% \mathrm{Si}$ sodium glass.

Raman spectra recorded on zones 2 and 5 identify a typical soda-lime glass, while spectra in zones 1 and 3 show the presence of phosphates. This heterogeneous composition indicates that the bead was made of a variety of recycled glasses and corroborates the existence of beads made of reused glass in the Khami period, as shown in reference 6.

\section{Discussion}

Raman and XRF analyses revealed that a fair number of the selected glass beads (marked with an X) from Magoro Hill, which had provisionally been assigned on morphologically grounds to the period pre-dating the seventeenth century, belong to the European series beads. These beads, together with the positively identified European beads, can undoubtedly be linked to the Venda occupation of the hill. The 1241 beads morphologically classified as belonging to the European bead series consist of the following morphological types: 118 red-ongreen ("green hearts"), 15 red-on-white ("white hearts"), 12 blue-on-white, 32 striped, 9 annular, 43 hexagonal, 3 round fancy, 250 seed (white, red, pink, light blue, green orange, clear) and 759 larger (black, cobalt blue, light blue, green, yellow, white, clear) tubes and cylinders. Several of these types appear in a catalogue of Venda heirloom beads (Fig. 11), which was compiled in 1950 and forms part of the Van Riet Lowe Collection at the University of the Witwatersrand. The following bead types depicted in the catalogue were retrieved from Magoro Hill: hexagonal (no. 1), annular (no. 7), large cobalt blue (no. 3), large white (nos. 4 and 5), smaller blue-grey tubes (no. 8), red-on-green (no. 13), red-brown tubes (no. 14) and all colours of small beads (no. 19).

In summary, beads imported into southern Africa before the seventeenth century could be recognised based on the classification system outlined in [6], utilising both XRF and Raman spectroscopy. However, a substantial number of beads of European origin that resemble the older series beads could not be classified correctly using morphological attributes only. It is known that by 


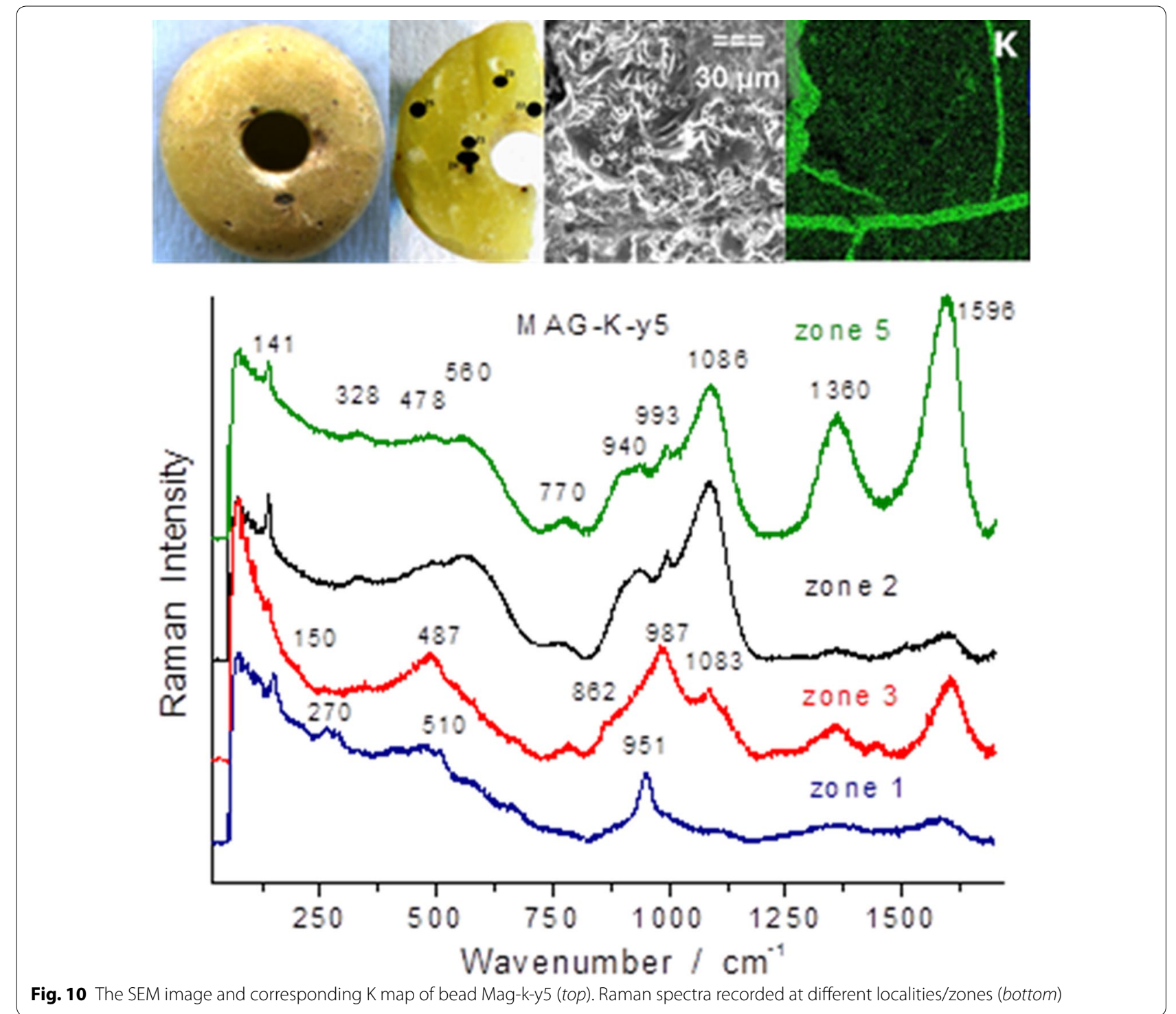

the time that trading partners shifted from South Asia (India) and Southeast Asia to Europe, beads had become a valued item of traditional attire in many southern African societies and many of the beads had special meaning for different African communities. African clients were not always satisfied with the new varieties of beads and efforts were made by trading partners to copy the older style beads [4]. For example, red-on-green beads, referred to as "green hearts", were produced in Venice to substitute the red-brown Khami beads imported from the East.

The morphological resemblance between some European beads and the earlier Indo-Pacific beads is also striking. This is borne out by supply-side sources as well. It is well known that Venice and Bohemia were principal centres for bead making. One of the most important exporters of beads to West Africa, acting as intermediary between bead producers and traders, was the firm of J.F. Sick and Co. When in 1964 the firm closed its office in Venice, it donated the sample collection of some 22000 Venetian glass beads kept in its head office in Amsterdam, as well as a catalogue of J.F. Sick $\mathcal{E}$ Co, Beads, to the Tropenmuseum, an ethnographic museum in Amsterdam. This collection is extensively discussed in the book, The bead goes on: the sample card collection with trade beads from the company J.F. Sick \& Co. in the Tropenmuseum, Amsterdam [42]. This German (later Dutch) company was one of the most important exporters of beads to West Africa in the first half of the twentieth century. The collection is available online and in chart 42 (Fig. 12) seed beads with similar colours and 


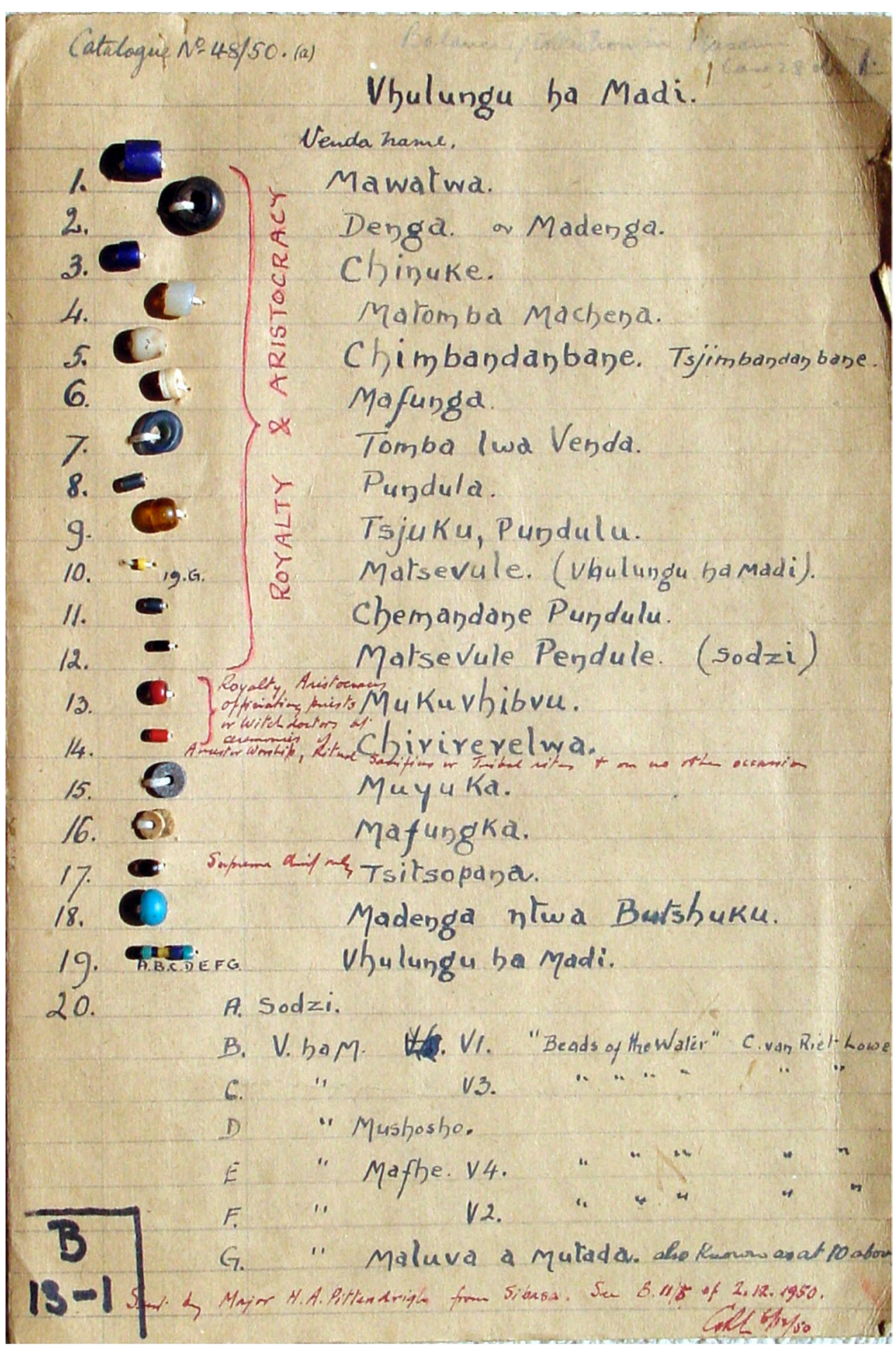

Fig. 11 Venda beads, Van Riet Lowe collection, University of the Witwatersrand (courtesy of Marilee Wood)

sizes as the Mapungubwe Oblates can be seen, as well as black beads that on morphological parameters resemble many of the black beads in the older series beads.
These beads were made in Gablonz (Jablonec), a city in the north-western part of the modern Czech Republic which served as the centre of the famous Bohemian 

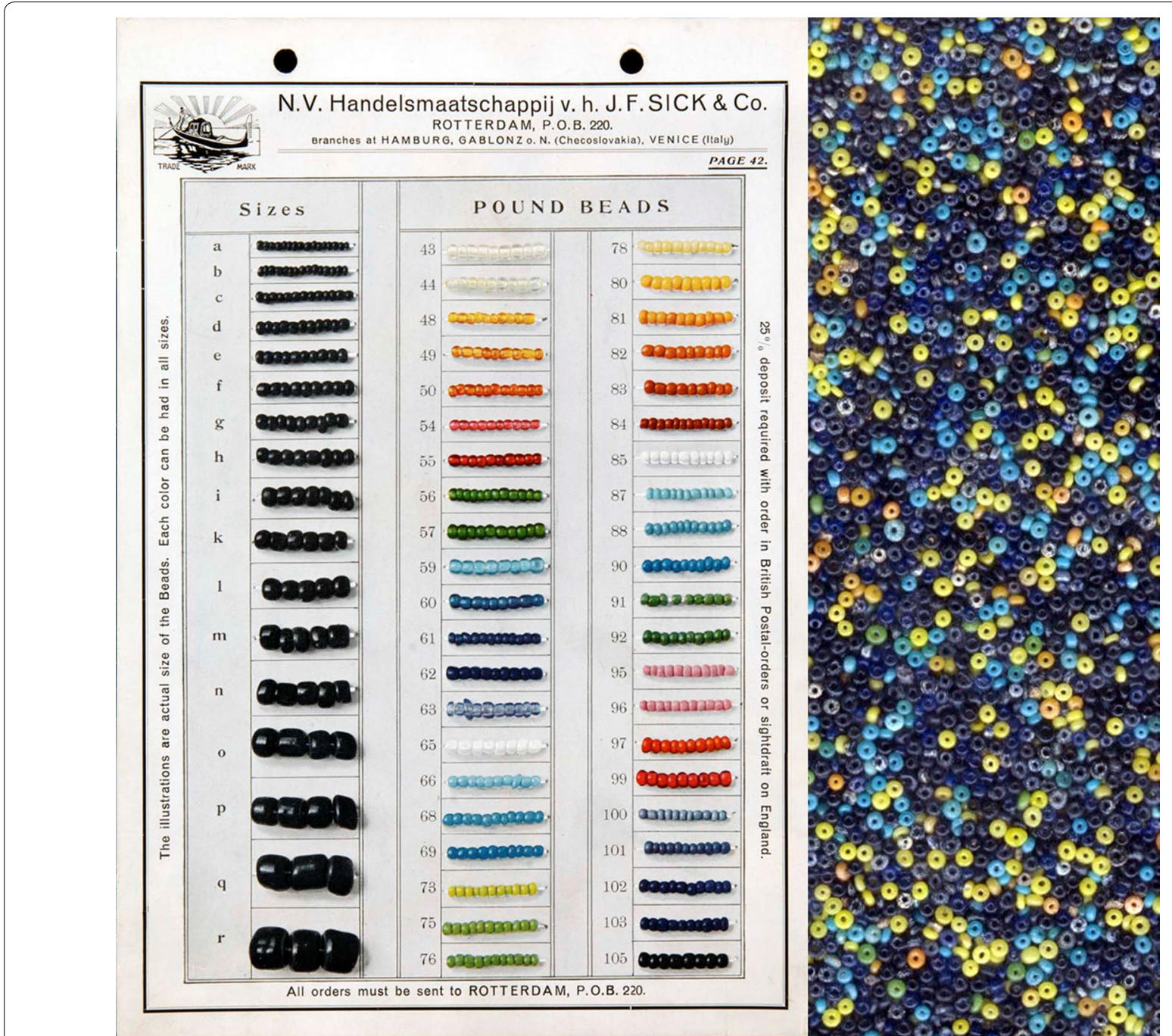

Fig. 12 Chart 42 in the 19 catalogue from the company J.F. Sick in the Tropenmuseum, Amsterdam (left) http://pivotcentraal.ab-c.nl/tradebeads and a selection of the Mapungubwe Oblates associated with the gold graves on Mapungubwe Hill (thirteenth c.)

glass industry. Unfortunately, these beads are not physically in the Tropenmuseum and could thus not be chemically analysed.

It is doubtful, however, if the resemblance between European beads and bead series dating several centuries earlier, such as for example the Mapungubwe Oblates, can be attributed to deliberate imitation. Rather the use of the same production method for the Mapungubwe and the European oblates may account for the resemblance between the beads. Importantly, from an archaeological perspective the Magoro Hill study has demonstrated that in cases where oblate beads are recovered from a multi-component site that includes a European-period occupation, physico-chemical analyses will be necessary to definitively distinguish the more recent oblates from older bead series. It is clear that a study of the glass recipes of the suppliers of beads will constitute a critical component of future investigations of beads traded into Africa after the sixteenth century AD.

\section{Conclusion}

These results illustrate that the classification of glass trade beads on morphological parameters only can be inconclusive, especially in sites with a long settlement record and a complex stratigraphy. In such cases, XRF and Raman spectroscopy are complementary and useful methods for identifying glass composition, heterogeneity due to 
recycling and pigments that can help to classify the beads correctly. Raman spectroscopy is a strong technique in identifying pigments in glass discriminating between bead series. On the other hand, XRF, by revealing the elemental compositions of the glass, can make a link between the glass bead series as well as glass groups and their Raman spectra. XRF also presents good information regarding the dissolved colourants, such as $\mathrm{Cu}, \mathrm{Fe}$ and $\mathrm{Co}$, as well as trace elements (As, Ag, U) accompanying them, that cannot be detected by Raman spectroscopy. The limitation of $\mathrm{XRF}$ in the detection of light elements such as $\mathrm{Na}$ and corroded surfaces of old glass beads as the result of lixiviation should be considered in the interpretation of the results.

The 1557 beads recovered from Magoro Hill were provisionally classified according to morphological attributes as Zhizo (19), K2 Indo-Pacific (17), East Coast IndoPacific (18 black, 60 red), Mapungubwe Oblates (148), Zimbabwe (14), Khami Indo-Pacific (40) and European (1241). Raman spectra were recorded on 9 Zhizo beads, 7 were analysed with XRF with end result that not one of them belong to the Zhizo bead series (see Additional file 1: Table S4). It is assumed that the other 10 beads not analysed also do not belong to this series. Only one K2-IP bead was positively identified from the 6 analysed, but this indicates that a few more might be present (see Additional file 1: Table S4). Only two of the Mapungubwe Oblate/Zimbabwe series beads were positively identified, but more might be present. A larger sample of black Khami Indo-Pacific series beads (10) was present in the sample, but most of the Magoro beads had a European origin. This distribution ties in with the archaeological assessment of the site, which suggests that the hill was only intermittently frequented by iron-using African farming communities prior to becoming the capital of the Venda chiefdom of Magoro in the second half of the eighteenth century AD. While most of the European trade beads probably reached Magoro Hill from entrepots in Mozambique along the eastern coast of Africa, others could have been derived from new trading networks further south with Natal and the Cape Colony, which emerged after the settlement of Dutch/Afrikaans colonists in the Soutpansberg on the northern South African frontier in 1848 .

\section{Additional file}

Additional file 1: Table S1. Report on XRF results of the main elements (wt \%) that act as glass former, stabilizer and flux in some K2, Mapungubwe, Zimbawe and Khami series from van Riet Lowe Collection. Table S2. Average composition of some glass bead series from southern Africa (oxides wt \%) [23]. Table S3. Reclassification of the beads from Table 2 Table S4. Reclassification of the beads from Table 3.

\section{Authors' contributions}

FK contributed to conception and design, acquisition of data (XRF and some Raman measurements) and was mostly responsible for the analysis and interpretation of data. She wrote the first draft of the manuscript and was part of the revision process. LCP was responsible and organized the design, data acquisition, analysis and interpretation of data, was involved in drafting the manuscript and revising it critically for important intellectual content and gave final approval of the version to be published. She is accountable for all aspects of the work relating to the accuracy and integrity of any part of the work. WB was part of the team that excavated Magoro Hill, classified the beads on their morphological parameters and recorded most of the Raman spectra under the supervision of Dr. Colomban in his laboratory in Paris. He contributed to the writing of the historical part of the document and as field archaeologists made many contributions in revising the manuscript critically. PC was part of the design and conceptualising of the project and supervised the collection of Raman data and the SEM/EDS measurements in Paris. He contributed in revising the manuscript critically for accuracy of scientific data, interpretation of results and comparing the work to the large body of work published on glass analyses. ATN was responsible for the SEM/EDS measurements and analyses of data. JCAB led the excavation team on Magoro Hill and was responsible for putting the beads in archaeological context and writing the archaeological and historical parts of the manuscript. MMR was part of the team excavating Magoro Hill and contributed to the archaeological and historical parts of the manuscript. KB contributed to placing the trade bead industry in perspective from the production sites in Europe. All authors read and approved the final manuscript.

\section{Author details}

${ }^{1}$ Department of Physics, University of Pretoria, Private Bag X20, Pretoria 0028, South Africa. ${ }^{2}$ Centre for Archaeological Science, School of Earth and Environmental Sciences, University of Wollongong, Wollongong, NSW 2522, Australia. ${ }^{3}$ UPMC Univ Paris 06, UMR 8233, MONARIS, Sorbonne Universités, 75005 Paris, France. ${ }^{4}$ CNRS, UMR 8233, MONARIS, 75005 Paris, France. ${ }^{5}$ Department of Anthropology and Archaeology, University of South Africa, Pretoria 0003, South Africa. ${ }^{6}$ Tropenmuseum, Linnaeusstraat 2, Amsterdam, The Netherlands.

\section{Acknowledgements}

The authors wish to thank Marilee Wood for supplying us with the image in Fig. 12 and datasheets of the chemical composition of some beads. Farahnaz Koleini and Linda C. Prinsloo acknowledge the financial contribution from the National Research Foundation (NRF) of South Africa and Philippe Colomban from EGIDE PROTEA

Competing interests

I hereby declare that all the authors have confirmed that they do not have competing interests.

Received: 10 July 2016 Accepted: 25 November 2016

Published online: 22 December 2016

References

1. Beaujard Ph. Les mondes de l'océan Indien-L'océan Indien, au cœur des globalisations de l'Ancien Monde ( $7^{e}-15^{e}$ siècle), vol. 2. Paris: Armand Colin; 2012

2. Wood M. Making connections: relationships between international trade and glass beads from the Shashe-Limpopo area. S Afr Archaeol Bull Goodwin Series. 2000;8:78-90.

3. Wood MH. Glass beads and pre-European trade in the Shashe-Limpoporegion, MSC. Johannesburg: University of the Witwatersrand; 2005.

4. Wood M. Post-European contact glass beads from the southern African interior: a tentative look at trade, consumption and identities. In: Swanepoel N, Esterhuysen A, Bonner P, editors. Five hundred years rediscovered. Johannesburg: Wits University Press; 2008. p. 183-96 (Plates 6-21).

5. Wood M. A glass bead sequence for Southern Africa from the eigth to the sixteenth century AD. J Afr Archaeol. 2011;9(1):67-84. 
6. Koleini F, Prinsloo LC, Biemond W, Colomban Ph, Ngo A-T, Boeyens JCA, van der Ryst MM. Towards refining the classification of glass trade beads imported into southern Africa from the eighth to the sixteenth century AD. J Cult Herit. 2016;19:435-44.

7. Saitowitz SJ. Nineteenth century glass trade beads from two Zulu royal residences. Cape Town: MA University of Cape Town; 1990.

8. Francis P. Beads of the world. A collector's guide with revised price reference. 2nd ed. Atglen: Schiffer Publishing Ltd; 1999.

9. Robertshaw P, Wood M, Haour A, Karklins K, Neff H. Chemical analysis, chronology, and context of a European glass bead assemblage from Garumele, Niger. J Archaeol Sci. 2014;41:591-604.

10. Prinsloo LC, Boeyens JCA, Van der Ryst MM, Webb G. Raman signatures of the modern pigment $(\mathrm{Zn}, \mathrm{Cd}) \mathrm{S}_{1-x} \mathrm{Se}_{\mathrm{x}}$ and glass matrix of a red bead from Magoro Hill, an archaeological site in Limpopo Province, South Africa, recalibrate the settlement chronology. J Mol Struct. 2012;1023:123-7.

11. Swanepoel N, Esterhuysen A, Bonner P, editors. Five hundred years rediscovered: Southern African precedents and prospects. Johannesburg: Wits University Press; 2008.

12. De Vaal JB. Ou handelsvoetpaaie en wapaaie in Oos- en Noord-Transvaal. Contree. 1984;16:5-15.

13. De Vaal JB. Die rol van João Albasini in die geskiedenis van die Transvaal. Archives year book of South African history. Part I. Cape Town: Elsiesrivier; 1953.

14. Huffman TN. Handbook to the Iron Age: the archaeology of pre-colonial farming societies in southern Africa. Scottsville: University of KwaZuluNatal Press; 2007.

15. Aukema JA. Rain-making: a thousand-year-old ritual. S Afr Archaeol Bull. 1989:44(150):70-2.

16. Huffman TN. Ritual space in pre-colonial farming societies in southern Africa. Ethnoarchaeology. 2012;4(2):119-46.

17. Phophi WMD. Vhuhosi ha vha ha Magoro. Muvenda! Dzhenala ya birou ya Tshivenda. 1981;8(2):14-8.

18. Boeyens JCA. "Black ivory": the indenture system and slavery in Zoutpansberg, 1848-1869. In: Eldredge EA, Morton F, editors. Slavery in South Africa: captive labor on the Dutch frontier. Boulder: Westview; 1994. p. $187-214$

19. Boeyens JCA. The intersection of archaeology, oral tradition and history in the South African interior. New Contree. 2012;64:1-30.

20. Prinsloo LC, Colomban Ph. A Raman spectroscopic study of the Mapungubwe oblates: glass trade beads excavated at an Iron Age archaeological site in South Africa. J Raman Spectrosc. 2008;39(1):79-90.

21. Prinsloo LC, Tournié A, Colomban Ph. A Raman spectroscopic study of glass trade beads excavated at Mapungubwe hill and K2, two archaeological sites in southern Africa, raises question about the last occupation date of the hill. J Archaeol Sci. 2011;38(12):3264-77.

22. Tournié A, Prinsloo LC, Colomban Ph. Raman classification of the glass beads excavated on Mapungubwe hill and K2, two archaeological sites in South Africa. J Raman Spectrosc. 2012;43(4):532-42.

23. Robertshaw P, Wood M, Melchiorre E, Popelka-Filcoff RS, Glascock MD. Southern African glass beads: chemistry, glass sources and patterns of trade. J Archaeol Sci. 2010;37(8):1898-912.

24. Colomban Ph. The destructive/non-destructive identification of enameled pottery, glass artifacts and associated pigments-a brief overview. Arts. 2013. doi:10.3390/arts2030077.

25. Koleini F, Pikirayi I, Colomban PH. Revisiting Baranda: a multi-analytical approach in the classification of sixteenth/seventeenth-century glass beads from Northern Zimbabwe. Antiquity. In press; 2016.

26. Beck HC. The beads of the Mapungubwe district. In: Fouché $L$, editor. Mapungubwe: ancient Bantu civilization on the Limpopo. Reports on excavations at Mapungubwe. Cambridge: Cambridge University Press; 1937. p. 104-13.
27. Rousaki A, Coccato A, Verhaeghe C, Clist BO, Bostoen K, Vandenabeele $P$, Moens L. Combined spectroscopic analysis of beads from the tombs of Kindoki, Lower Congo Province (Democratic Republic of the Congo). Appl Spectrosc. 2016;70(1):76-93.

28. Fischbach N, Ngo A, Colomban Ph, Pauly M. Beads excavated from Antsiraka Boira necropolis (Mayotte Island twelfth-thirteenth century); colouring agents and glass matrix composition comparison with contemporary southern Africa sites. Archeosciences-rev Archéométrie. In press; 2016.

29. Feng DU, BaoRu SU. Further study of sources of the imported cobalt-blue pigment used on Jingdezhen porcelain from late 13 to early 15 centuries. Sci China Ser E. 2008;51(3):249-59.

30. Wood M, Panighello S, Orsega FE, Robertshaw P, van Elteren JT, Crowther A, Horton M, Boivin N. Zanzibar and Indian Ocean trade in the first millennium CE: the glass bead evidence. Archaeol Anthropol Sci. 2016. doi:10.1007/s12520-015-0.310-z.

31. Colomban Ph, Huy LQ, Liem NQ, Mazerolles L. Vietnamese (fifteenth century) blue-and white, Tam Thai and lustre porcelains/stonewares: glaze composition and decoration techniques. Archaeometry. 2004;46:125-36.

32. Raposo JC, Zuloaga O, Olazabal MA, Madariaga JM. Study of the precipitation of arsenate anion with calcium and magnesium in sodium perchlorate at $25^{\circ} \mathrm{C}$. Appl Geochem. 2004;19(6):855-62.

33. Kirmizi B, Colomban Ph, Blanc M. On-site analysis of Limoges enamels from sixteenth to nineteenth centuries: an attempt to differentiate between genuine artefacts and copies. J Raman Spectrosc. 2010:41(10):1240-7.

34. Ricciardi P, Colomban Ph, Tournié A, Macchiarola M, Ayed N. A noninvasive study of Roman age mosaic glass tesserae by means of Raman spectroscopy. J Archaeol Sci. 2009;36(11):2551-9.

35. Bonneau A, Moreau J-F, Auger R, Hancock RGV, Émard B. Analyses physico-chimiques des perles de traite en verre de facture européenne: quelles instrumentations pour quels résultats? Archéologiques. 2013:26:109-32.

36. De Vaal JB. Handel langs die vroegste roetes. Contree. 1985;17:5-14.

37. Van Riet Lowe C. The glass beads of Mapungubwe, Archaeological series no. 9. Union of South Africa: Archaeological Survey; 1955.

38. Zuchchiatti A, Bouquillon A, Katona I, D'Alessandro A. The 'della Robbia blue': a case study for the use of cobalt pigments in ceramics during the Italian Renaissance. Archaeometry. 2006;48(1):131-52.

39. Gratuze B, Soulier I, Barrandon JN, Foy D. De l'origine du cobalt dans les verres. Revue d'Archéometrie. 1992;16:97-108.

40. Colomban Ph. Lapis lazuli as unexpected blue pigment in Iranian Lajvardina ceramics. J Raman Spectrosc. 2003;34(6):420-3.

41. Colomban Ph. Polymerisation degree and Raman identification of ancient glasses used for jewellery, ceramics, enamels and mosaics. J Non-Cryst Solids. 2003:323(1):180-7.

42. Van Brakel K. The bead goes on: the sample card collection with trade beads from the company JF Sick \& Co. in the Tropenmuseum, Amsterdam. Amsterdam: KIT Publishers; 2006.

\section{Submit your manuscript to a SpringerOpen ${ }^{\circ}$ journal and benefit from:}

- Convenient online submission

- Rigorous peer review

- Immediate publication on acceptance

- Open access: articles freely available online

- High visibility within the field

- Retaining the copyright to your article

Submit your next manuscript at $\boldsymbol{\nabla}$ springeropen.com 